NBER WORKING PAPER SERIES

\title{
SOME ECONOMIC ASPECTS OF ANTITRUST ANALYSIS IN DYNAMICALLY COMPETITIVE INDUSTRIES
}

\author{
David S. Evans \\ Richard Schmalensee \\ Working Paper 8268 \\ http://www.nber.org/papers/w8268 \\ NATIONAL BUREAU OF ECONOMIC RESEARCH \\ 1050 Massachusetts Avenue \\ Cambridge, MA 02138 \\ May 2001
}

Paper prepared for the NBER conference on Innovation Policy and the Economy, Washington, DC, April 17, 2001. The authors are indebted to Microsoft for research support, to Kirstyn Walton and Bryan MartinKeating for research assistance, and to Albert Nichols and Bernard Reddy for valuable comments. Only the authors are responsible for opinions expressed in this essay and for its shortcomings. The views expressed herein are those of the authors and not those of the National Bureau of Economic Research. The views expressed herein are those of the authors and not necessarily those of the National Bureau of Economic Research.

(C) 2001 by David S. Evans and Richard Schmalensee. All rights reserved. Short sections of text, not to exceed two paragraphs, may be quoted without explicit permission provided that full credit, including (C) notice, is given to the source. 
Some Economic Aspects of Antitrust Analysis in Dynamically Competitive Industries David S. Evans and Richard Schmalensee

NBER Working Paper No. 8268

May 2001

JEL No. L4

\section{ABSTRACT}

Competition in many important industries centers on investment in intellectual property. Firms engage in dynamic, Schumpeterian competition for the market, through sequential winnertake-all races to produce drastic innovations, rather than through static price/output competition in the market. Sound antitrust economic analysis of such industries requires explicit consideration of dynamic competition. Most leading firms in these dynamically competitive industries have considerable short-run market power, for instance, but ignoring their vulnerability to drastic innovation may yield misleading conclusions. Similarly, conventional tests for predation cannot discriminate between practices that increase or decrease consumer welfare in winner-take-all industries. Finally, innovation in dynamically competitive industries often involves enhancing feature sets; there is no sound economic basis for treating such enhancements as per se illegal ties.

David S. Evans

National Economic Research Associates

One Main Street

Cambridge, MA 02142

David.Evans@NERA.com
Richard Schmalensee

Sloan School of Management Massachusetts Institute of Technology

Room E52-474, 50 Memorial Drive

Cambridge, MA 02142

and NBER

rschmal@mit.edu 


\section{INTRODUCTION}

This paper is about the economics of antitrust in industries that are undergoing rapid technological change and in which competition centers on investment in intellectual property. In many of these industries, firms engage in dynamic competition for the market - usually through research-and-development (R\&D) competition to develop the "killer" product, service, or feature that will confer market leadership and thus diminish or eliminate actual or potential rivals. Static price/output competition on the margin in the market is less important.

Heavy investment in the creation of intellectual property typically results in significant scale economies, leading to substantial seller concentration. ${ }^{1}$ Market leadership may nevertheless be contestable as a result of the constant threat of drastic innovations by rivals. In the popular press, these industries are sometimes referred to as "new-economy" or "high-technology." Many have aspects that economists would call "Schumpeterian" after the economist who described the process of "creative destruction" whereby innovation destroys old industries and creates new ones. $^{2}$ In contrast, in "old-economy" industries, competition takes place primarily through traditional price/output competition on the margin in the market and through incremental innovation, not through efforts to create drastic_- market-destroying-innovations. ${ }^{3}$

The federal antitrust enforcement agencies have viewed new-economy industries as particularly susceptible to breakdowns in competition and thus deserving of particularly close

\footnotetext{
${ }^{1}$ This is a general characteristic of industries with "endogenous sunk costs," in which spending on advertising, research, or product design and development is an important aspect of competition (see Sutton (1991) and Schmalensee (1992)). It is, however, more pronounced in high-technology industries.

${ }^{2}$ See the discussion of dynamic competition in Schumpeter (1950, pp. 81-86).

${ }^{3}$ Although we use this new-economy/old-economy distinction throughout, the fundamental difference is between industries in which competition is mainly for the market and industries in which competition is mainly in the market.
} 
antitrust scrutiny. ${ }^{4}$ We argue that this broad-brush approach is unlikely to enhance consumer welfare. We do not contend that dynamically competitive industries should be immune to careful antitrust scrutiny, nor that the basic principles of antitrust should be modified in these sectors. Fixing prices or preventing competitors from distributing their products will generally harm consumers even if dynamic competition is vigorous. Nonetheless, the application of antitrust principles should take account of the important ways new-economy industries differ from traditional ones. In recent decades, careful use of economic analysis has generally aligned antitrust policy more closely with the interests of consumers. To continue this trend, antitrust policy must reflect the features of dynamically competitive industries (many new-economy industries) that differentiate them from statically competitive industries (most old-economy industries).

Part II briefly documents the growing importance of new-economy industries, identifies some important industries in which competition is mainly dynamic, and discusses key economic aspects of new-economy industries. Part III considers how the central features of new-economy industries affect the market definition and market power analysis that has become central to the practice of antitrust economics. Part IV examines how these economic characteristics affect the analysis of predation claims - charges that a business has acted to exclude or eliminate rivals to acquire or maintain a monopoly. Part V then examines the antitrust economics of tyingrequiring customers to purchase one product as a condition of purchasing another-in neweconomy industries. Finally, Part VI summarizes lessons for antitrust policy in the new economy. Although our analysis applies generally, we draw our examples in Parts III-V mainly from

\footnotetext{
${ }^{4}$ See Klein (2000), Pitofsky (1999), Baer and Balto (1998/1999), and Rubinfeld (1998).
} 
United States v. Microsoft Corp., the leading antitrust case to date involving a new-economy industry. ${ }^{5}$

\section{NEW-ECONOMY INDUSTRIES}

\section{A. What's New?}

The defining feature of new-economy industries is a competitive process dominated by efforts to create intellectual property through $\mathrm{R} \& \mathrm{D}$, which often results in rapid and disruptive technological change. Particularly at the height of the boom in "dot-com" stock prices, many authors have exaggerated the importance of such industries and of intellectual property more generally. Nonetheless, the U.S. economy has undergone an important transformation in the last 30 years that has resulted in much "creative destruction" and increased investment in innovation. ${ }^{6}$ Table 1 compares the U.S. companies with the 20 largest market capitalizations at the end of 1970, 1985, and 2000. Only five companies from the 1970 and 1985 lists (IBM,

General Electric, BP Amoco, Exxon Mobil, and Coca-Cola) made the top 20 in 2000; more than half of the companies on the 2000 list did not even exist in 1970, including Microsoft, Cisco Systems, Oracle, and EMC. ${ }^{7}$ The top three firms in 1970 (IBM, AT\&T, and General Motors) were still in the top five in 1985 but had been substantially displaced by 2000. AT\&T and General Motors fell out of the top 20 altogether, while IBM — an "old" new-economy company

\footnotetext{
${ }^{5}$ The authors were consultants to Microsoft in United States v. Microsoft Corp., and Schmalensee testified on behalf of Microsoft. See Evans, Nichols, and Schmalensee (2001). Some of the general issues discussed here are also treated, in less detail, in Evans (2001b), Evans and Schmalensee (2000), and Schmalensee (2000). For an application to European antitrust law see Ahlborn, Evans, and Padilla (2001).

${ }^{6}$ For further discussion, see Levin and Reiss (1984).

${ }^{7}$ FactSet Research Systems (2001).
} 
that barely survived the drastic innovations that sharply reduced the demand for its mainframe computers-fell to $18^{\text {th }}$ place.

Many of the new firms on the list in 2000 are part of what has come to be called the new economy: companies whose fortunes are tied to success in the creation of intellectual property and are highly vulnerable to successful innovation by others. The firms listed in 1970 and 1985 but not in 2000 are what have come to be called the old-economy companies: firms whose fortunes are tied to the use of mature technologies in which drastic innovation is rare, such as food manufacturing and petroleum production. For example, 1999 R\&D expenditures averaged 3.6 percent of sales for still-existing companies that had been on the top-20 list for 1970 and 3.0 percent for those on the 1985 list, while the average ratio was 6.8 percent for the companies on the top-20 list for $2000 .^{8}$

We see the increased importance of the creation of intellectual property in other ways. Company-funded R\&D as a percentage of GDP was generally below 1.0 percent from 1958 to 1979; it was generally above 1.4 percent in the 1990 s. $^{9}$ In 1950 not one of the 100 highest valued firms spent more than 5 percent of revenues on R\&D, and in 1970 only nine of the top 100 exceeded this level. But in 1999, 38 of the 100 highest valued firms spent at least 5 percent of revenue on $R \& D$, with 22 firms spending more than 10 percent. $^{10}$

The new economy is almost synonymous with the information-technology industries. Of course, these industries, broadly defined, have been around for a long time. The Bell System,

\footnotetext{
${ }^{8}$ Id.; 1999 10-K reports of Eastman Kodak Co, Ford Corp, General Motors Corp, ITT Industries, and Xerox Corporation.

${ }^{9}$ R\&D expenditures provided by National Science Foundation (1969, Table B-8), (1981, Table B-5), (1992, Table A-7), (1998, Table A-7). Nominal GDP from the Council of Economic Advisors (2000, Table B-1).
} 
formed in the late $19^{\text {th }}$ century, was a network industry created by a drastic invention and based on the transmission of information. Mainframe computers became a big business in the 1950s and was considered a mature industry by the late 1970s. But rapid increases in microprocessor speeds, decreases in the cost of providing bandwidth, and the development of the Internet have, in the last 25 years, fostered the creation of many industries that have Schumpeterian dimensions. These include computer software (e.g., operating systems, applications, and utilities), computer hardware (e.g., microprocessors, personal computers and servers), and Internet-based businesses (e.g., portals, business-to-business exchanges and content providers). ${ }^{11}$

There are other industries, however, that have been born or revolutionized in the last quarter century and in which dynamic competition is fundamental. These include communications networks (routers and related equipment), mobile telephony, and biotechnology. A much older industry, pharmaceuticals, has some Schumpeterian characteristics as well. ${ }^{12}$ Table 2 lists the leading industrial firms whose expenditures on $R \& D$ accounted for more than 10 percent of their sales in $1997 .{ }^{13}$ More than one quarter of these R\&D-intensive companies were

(...continued)

${ }^{10}$ Companies were ranked by year-end market value in 1950,1975 , and 1999 . Companies for which R\&D data were not reported were assumed to have expended negligible amounts. Market value, net sales, and R\&D data obtained from FactSet Research Systems (supra note 7).

${ }^{11}$ For a discussion of the economic role of information-technology industries, see Jorgenson (2001).

${ }^{12}$ Gans, Hsu, and Stern (2000) suggest that the extent to which dynamic competition is important varies across technology-intensive industries. Specifically, they argue that an innovator may earn returns on her innovation either through product market competition (i.e., dynamic competition in which the innovator develops a new product and then competes against the incumbent[s]) or by selling her innovation in a "market for ideas" (i.e., cooperating with the incumbent[s] through licensing, strategic alliances, or acquisition). They find that the probability of cooperation increases with the strength of intellectual property rights, lower bargaining costs, and the relative cost of control of specialized complementary assets. The authors suggest that we can observe the former in many areas of the electronics industry and computer software and the latter in the pharmaceutical industry.

${ }^{13}$ Shepherd and Payson (1999, Table 3). Data are based on Standard \& Poor's Compustat, Englewood, Co. 
among the 50 highest valued companies at the end of $2000 .{ }^{14}$ Most of these would be characterized as high-technology or new-economy companies and have their fortunes tied to their success at innovation.

\section{B. Key Characteristics}

Industries in which dynamic competition for the market is important have several of the following characteristics. Each characteristic reflects a deviation from the textbook model of static price/output competition and has important implications for antitrust analysis.

\section{Low-Marginal Costs/High Fixed Costs}

Firms in new-economy industries tend to have high fixed costs and low marginal production costs. They often must invest a great deal to develop their products, either because they must make substantial investments in $\mathrm{R} \& \mathrm{D}$, or because they must invest in a physical or virtual network to create and deliver the product. But once they make this initial investment, it is cheap to create additional units. It does not cost much to produce another copy of, say, the Adobe Acrobat Reader; nor, once a fabrication facility has been set up, to produce another Intel Pentium microprocessor. That is, production in new-economy industries exhibits "increasing returns." For example, in 1998 material expenses accounted for 52 percent of revenues in manufacturing industries overall, ${ }^{16}$ while in new-economy industries material expenses averaged less than 30

\footnotetext{
${ }^{14}$ Supra note 7.

${ }^{15}$ Of course, some old-economy industries (such as gas, electricity and railways) also have increasing returns or supply-side economies of scale.

${ }^{16}$ U.S. Bureau of the Census (2000, Table 2).
} 
percent of revenues (for example, software (19 percent), ${ }^{17}$ pharmaceuticals $(29 \text { percent })^{18}$ and semiconductor manufacturing (19 percent $\left.)^{19}\right)$.

\section{Labor and Human Capital Intensity}

Many new-economy industries make more intensive use of labor and less intensive use of tangible capital than old-economy industries. That is because the fixed costs incurred by hightechnology firms are mainly for the labor used to develop their products, by developing intellectual property (or intangible capital). Thus, even if the subsequent production process is fairly capital-intensive, as in chip manufacturing for instance, new-economy industries are generally relatively labor-intensive overall. Labor costs are 15 percent of revenue in manufacturing industries overall as compared to 22 percent in electromedical equipment, 30 percent in software publishing, and 48 percent in computer programming services. ${ }^{20}$

Another important reason why labor compensation accounts for a high fraction of the costs in high-technology industries is that they tend to have more highly educated workforces than old-economy industries; accordingly they tend to use more human capital. ${ }^{21}$ For example, the median education level of workers in the software industry is 15 years, while workers in all

\footnotetext{
${ }^{17}$ Material expenses for software are measured as the weighted average of the ratio of cost of goods sold to revenue for the ten largest software firms (measured by net sales in 1997). Based on Form 10-K's for Microsoft, Compuware, Novell, Cadence Design, Adobe, Electronic Arts, Sybase, and Peoplesoft. Cost of goods sold data were unavailable for Oracle and Computer Associates.

${ }^{18}$ U.S. Bureau of the Census (1999b, Table 1). The NAICS code for pharmaceutical preparation is 325412. Data are for 1997.

${ }^{19}$ U.S. Bureau of the Census (1999a, Table 1). The NAICS code for semiconductor and related devices is 334413. Data are for 1997.

${ }^{20}$ Labor costs are measured as the ratio of annual payroll to sales, receipts, or value of shipments. Manufacturing encompasses SIC codes 20-39, electromedical equipment encompasses SIC code 3845, software publishing encompasses SIC code 7372, and computer programming services encompasses SIC code 7371. U.S. Bureau of the Census (1999c).

${ }^{21}$ Becker (1975).
} 
manufacturing have a median education level of 12 years. Moreover, 15.6 percent of workers in the software industry have a graduate degree, as compared to 4.6 percent in all manufacturing. ${ }^{22}$

Because intellectual property is the critical asset in new-economy industries, entry costs can be quite low, and the risk that a dangerous rival will emerge seemingly from nowhere can be quite high. For example, the Linux operating system, initially written by a graduate student as a hobby and further developed by volunteers working through the open-source movement on the Internet, has captured a 24.4 percent share of new installations on servers. ${ }^{23}$ Another open-source product, Apache, has captured a 60 percent share of installations on Web servers. ${ }^{24}$

\section{Network and System Effects}

Many high-technology industries, particularly those based on computer software, the Internet, or telecommunications generally, have network effects. An industry is often described as a "network industry" if the value of the network to any one consumer depends importantly, either directly or indirectly, on the number of other consumers on the network. ${ }^{25}$ Such an industry may or may not involve an actual physical network. Commonly cited examples of network industries include telephones, fax machines, credit card systems, and email. Many of these involve a physical network to link consumers, ${ }^{26}$ but the physical network is not really what makes these network industries in an economic sense. Some other network industries are clearly

${ }^{22}$ U.S. Bureau of Labor Statistics (1997-1999).

${ }^{23}$ International Data Corporation (2000b, Table 3).

24 “The Netcraft Web Server Survey," available at $<$ http://www.netcraft.com/survey/ $>$.

${ }^{25}$ See Evans and Reddy (1996), Evans and Schmalensee (1996, p. 40), Besen and Farrell (1994, p. 131), Liebowitz and Margolis (1994, p. 150), Katz and Shapiro (1994, p. 115), and Gilbert (1992, p. 8), for summaries of findings in the network economics literature.

${ }^{26}$ Fax machines generally rely on the public telephone network, not on a specialized "fax" network. Email generally relies on networks that are used for many other purposes, such as the Internet and corporate, academic, and government networks. 
"virtual" (not physical) networks, in which consumers benefit indirectly from the number of users of the network. In all cases, the use of common standards plays a critical role in linking network users. Network effects are a source of scale economies - in consumption rather than production — and thus tend to produce markets with at most a small number of clear leaders, making it difficult for firms with small shares to survive unless they produce significant innovation.

Many of the high-technology industries that have emerged in the last twenty years have significant network effects. Wintel computers (i.e., computers in which Windows software runs on Intel-compatible hardware) are more valuable to each consumer the more other consumers use this standard. Software developers will invest more in writing applications for this standard, making it more likely that consumers will have the applications they desire. Also, use of a common standard makes it easier for consumers to exchange input and output files (such as data sets, text documents, or spreadsheets) with each other.

Many Internet-based businesses also have significant network effects. That is perhaps most clearly true for messaging services and chat-rooms, the value of which directly increases with the number of people on the same network. It is also true for market-making services such as eBay, where buyers benefit from there being more sellers, and sellers benefit from there being more buyers.

Firms that are not leaders in network industries generally have little hope of reaching that status unless they come up with a major innovation—one that can defeat the natural advantage that network effects bestow on the industry leaders. Incremental innovation-making slight improvements in the leaders' products - will not enable a small firm to overtake a leader that enjoys the benefits of network economies. Similarly, the possibility of being displaced by a 
major innovation will shape leaders' research agendas. If there is a chance that today's products will be replaced by a major innovation, a leader's survival depends on bringing that innovation to market and thereby replacing itself before others do. As a result, competition in network industries often involves intense R\&D efforts aimed at capturing or retaining market leadership.

System effects - in which the value of one component of a system depends on complementary components in the system ${ }^{27}$ —are important in computer- and Internet-related high-technology industries. The value of any software platform, such as Windows or Java, depends largely on the quality and quantity of applications written to run on that platform, as well as on the ability of available hardware to run that platform with both speed and reliability. Firms in high-technology industries have strong incentives to encourage production of highquality complements. This welfare-enhancing activity generally requires a good deal of interfirm communication of various sorts.

\section{Innovation as a Series of Winner-Take-All Races}

Competition in some high-technology industries involves sequences of races to develop a new product or, as discussed above, to replace an existing product through drastic innovation. In the initial race, firms invest heavily to develop a product that creates a new category or becomes an early leader in a new category - the PalmPilot, VisiCorp's spreadsheet for the Apple, and AOL's Instant Messenger are examples. Winners get large market shares and high profits for a

\footnotetext{
${ }^{27}$ See Economides (1996).
} 
while. ${ }^{28}$ Economic theorists have produced numerous models of races of this sort, typically involving patents or network effects. ${ }^{29}$

In most of this literature, any given industry is assumed for simplicity to experience one and only one race, after which the winner enjoys a monopoly position forever. ${ }^{30}$ Unfortunately, this literature seems to have suggested to some observers that real new-economy industries also become stable monopolies after an initial burst of dynamic competition. While it is true that network effects tend to reinforce leadership positions, in many high-technology industries there are multiple, sequential races for market leadership. Major innovations occur repeatedly, and switching costs and lock-in do not prevent displacement of category leaders by better products. Figure 1 illustrates this phenomenon in the microcomputer software industry. ${ }^{31}$ It is not atypical for a fringe firm that invests heavily to displace the leader by leapfrogging the leader's technology.

These winner-take-all races arise for two related reasons discussed above. ${ }^{32}$ First, network effects create a snowball effect (sometimes called "positive feedback") for firms that are first to have many satisfied customers. When a firm attracts additional customers, the value of its product increases, making it possible to attract still more consumers. Second, there are scale economies at the firm level because of high fixed intellectual property costs, so that making more

\footnotetext{
${ }^{28}$ For example, Ford Motor Company introduced the Model T in 1909 and achieved a 40 percent share of U.S. automobile sales by 1925 . However, the Model T remained essentially unchanged, and after General Motors introduced heavier closed-body cars, Ford's market share dropped to 10 percent by 1927. See Waldman and Jensen (1998, pp. 270-272).

${ }^{29}$ See, e.g., Katz and Shapiro (1994), Reinganum (1989); Katz and Shapiro (1985), Gilbert and Newbery (1982).

${ }^{30}$ There are, however, some exceptions in which the authors consider models of ongoing dynamic competition. See, e.g., Vickers (1986) and Reinganum (1985).

${ }^{31}$ Shares from Margolis and Liebowitz (1999). For further discussion, see Evans, Nichols, and Reddy (1999).

${ }^{32}$ Most races could be more accurately described as "winner-take-most." However, for the sake of simplicity, we will use the term "winner-take-all" throughout.
} 
sales enables firms to get their average costs down and to make profits while charging low prices. In some high-technology industries, especially those based on the Internet, network effects and scale economies are so pronounced that many firms give away their products for extended periods of time, both to gain market penetration and to affect the evolution of technical standards. Netscape, for example, followed its famous "free, but not free" approach to market penetration of its web browser. ${ }^{33}$

Of course, in any particular industry, in either the new or the old economy, there is no guarantee that competition through races for drastic innovations will continue indefinitely. In the U.S. automobile industry, an initial period of rapid innovation and product development was followed by several decades of comparative stability. One might have described the auto industry in 1910 as Schumpeterian in important respects; one would not have said this in 1950.

On the other hand, a period of stability in market positions as measured by current sales can mask a fierce product development contest. Even though by 1990 Microsoft's MS-DOS had been far and away the leading PC operating system for almost a decade, Microsoft was engaged in a bet-the-company battle to develop a version of its Windows operating system product that would prevail against IBM's OS/2. ${ }^{34}$ By 1990, DOS-type operating systems were generally viewed as obsolete - deficient in handling memory, running multiple applications simultaneously, and providing ease of use. Microsoft had worked with IBM in developing early versions of $\mathrm{OS} / 2$, an operating system designed to overcome these deficiencies, but by the early 1990s the two firms had gone their separate ways. In early 1992, IBM released the first widely praised version of OS/2 at about the same time that Microsoft released Windows 3.1. Industry

\footnotetext{
${ }^{33}$ Cusumano and Yoffie (1998, pp. 97-100).

${ }^{34}$ Evans, Nichols, and Reddy (supra note 31 ).
} 
analysts at the time disagreed in their predictions over which would be more successful. ${ }^{35} \mathrm{~A}$ similar pairing of hotly competing products appeared in late 1994 and mid-1995, with the releases of OS/2 Warp 3.0 and Windows $95 .^{36}$ Again, analysts disagreed over which product would ultimately prevail. ${ }^{37}$

\section{Highly Profitable Industry Leaders}

For firms to be willing to engage in dynamic competition, they must expect to earn, on average, a competitive rate of return on their R\&D investments. These investments are risky, for competitive as well as technological reasons. With some probability, a firm's R\&D spending will produce no returns at all. For its expected rate of return to be competitive, it must be the case that if these investments succeed, they at least temporarily produce enough market power-enough ability to charge prices that exceed the corresponding marginal costs of production - to yield a supra-competitive rate of return viewed ex post.

Firms that expected that they would only be able to charge prices equal to marginal costs after completing their research and development successfully would obviously not invest in that research and development to begin with: they would not even recover their fixed and sunk R\&D costs. In dynamically competitive industries, entrepreneurs and their backers recognize that many will try and most will fail. In the aggregate, we expect that entrepreneurs and investors will keep investing until the expected rate of return, adjusted for risk, is equal to what they can get elsewhere in the economy. But these investments will fund many enterprises that do not

\footnotetext{
35 See, e.g., Gookin (1992).

${ }^{36}$ IBM introduced OS/2 Warp 3.0 in November 1994. Microsoft shipped Windows 95 in August 1995. See Miller (1995a) and Markoff (1995).

${ }^{37}$ See, e.g., Trimble and DeVoney (1995); Miller (1995b, “...Windows 95 the best choice for most PC users.”); Petreley (1995, “I believe OS/2 will win the 32-bit desktop war over Windows 95.”).
} 
succeed — and therefore lose money — and a few enterprises that do succeed—and therefore make a great deal of money. Expected and observed returns are thus highly skewed. ${ }^{38}$

Similarly, because of network effects and scale economies, as well as legally protected intellectual property, high-technology industries generally have a small number of relatively large firms at any point in time. In fact, in many new-economy industries these features may result in a single firm having the bulk of industry sales at any point in time.

\section{Dynamic vs. Static Competition in Antitrust Analysis}

Just over a half-century ago, Joseph Schumpeter described dynamic competition centered on drastic innovation as the "perennial gale of creative destruction" that sweeps away the old economic order and argued that it was the main source of economic progress. ${ }^{39}$ He noted the importance for consumer welfare of "competition from the new commodity, the new technology ... competition which strikes not at the margins of the profits of the existing firms but at their foundations and their very lives." ${ }^{40}$ Andy Grove, the former CEO of Intel, summarized business life for those in the path of these gales of creative destruction: "Only the paranoid survive.",41

In contrast, most economic texts and antitrust casebooks treat perfect competition as the welfare-maximizing market structure and treat departures from this structure as problematic. ${ }^{42}$ Of course, perfect competition is to economics what the frictionless plane is to physics: an abstract ideal that is never attained in reality. More importantly, perfect competition is an ideal only as

\footnotetext{
${ }^{38}$ Lerner (1998).

${ }^{39}$ Supra note 2.

${ }^{40} I d$., p. 84.

${ }^{41}$ Grove (1996).

${ }^{42}$ See, e.g., Mankiw (1998, p. 284).
} 
regards static competition; nobody argues that it is an effective, let alone ideal, regime for producing innovation through dynamic competition. Where dynamic competition is actually or potentially important as a source of consumer benefit, basing antitrust policy on the notion that perfect competition is an attainable ideal is unlikely to serve consumers well.

Nonetheless, antitrust analysis has historically taken departures from textbook perfect competition as signs of possible competitive problems that may warrant government intervention. ${ }^{43}$ In assessing the importance of those departures, antitrust analysis has traditionally paid particular attention to whether any firms have high market shares, since having a large number of relatively small firms is a key feature of perfect competition. However, as discussed just above, this statically competitive market structure cannot persist in many new-economy industries. Similarly, leaders in many new-economy industries generally set prices well above marginal cost and enjoy high rates of return even when dynamic competition is intense.

There are three important implications for antitrust economic analysis. First, the rational expectation of significant market power for some period of time is a necessary condition for dynamic competition to exist in high-technology industries. Thus if dynamic competition is healthy, the presence of short-run market power is not a symptom of a market failure that will harm consumers. Second, one expects leaders in new-economy industries to charge prices well above marginal cost and to earn high profits. It is natural in dynamic competition, not an indicator of market failure, for successful firms to have high rates of return even adjusting for risks they have borne. In effect, their lottery tickets have paid off. Third, although static competition is rarely vigorous in new-economy industries, the key determinant of the

\footnotetext{
${ }^{43}$ In practice, most antitrust analysis in the last fifty years has been based on the "structure-conduct-performance" model that seeks to determine the extent to which an industry lies between the extremes of perfect competition
} 
performance of these industries is the vigor of dynamic competition — an issue that is ignored by traditional antitrust analysis. ${ }^{44}$ An explicit investigation of present and likely future dynamic competition is essential to sound economic analysis of Schumpeterian industries.

Some observers have contended that the complexity of high-technology markets argues against the use of simple rules of antitrust policy and in favor of widespread use of detailed ruleof-reason analysis. On the other hand, such rule-of-reason analysis tends to be time-consuming, and the high rate of technological progress in these sectors and the fragility of market positions based on intangible assets mean that analyses of new-economy industries require access to specialized technical knowledge and rapidly become dated. Based on these concerns, Judge Richard Posner (2000) has noted his doubts that government officials can access the technical information necessary for sound analysis and that the judicial system can process new-economy antitrust cases before they are overtaken by events. The only apparent approach to the mitigation of these problems is to develop presumptions and structured rules of reason that reflect neweconomy realities and that are designed to lighten the courts' analytical burden. When the world is changing rapidly, an approximate analysis of today's conditions is much more likely to be useful than an exact analysis of conditions a decade ago.

\footnotetext{
(...continued)

and monopoly. This model is perhaps most explicit in the Horizontal Merger Guidelines. U.S. Department of Justice (1997).

${ }^{44}$ Economists in the Clinton administration recommended that "innovation markets" be defined and used for some antitrust analysis, particularly involving mergers between firms that might potentially compete in developing new products, even if their existing products do not compete; see Gilbert and Sunshine (1995a,b). While this approach pays at least some attention to sources of innovation, its implementation has been heavily criticized: Hay (1995); Rapp (1995); Hoerner (1995); and Carlton (1995).
} 


\section{MARKet Definition AND MARKet POWER}

\section{A. The Market Share Approach}

Many business practices are suspect under the antitrust laws only if the firms engaging in them have significant market power. ${ }^{45}$ Business practices such as tying the sale of two or more products, entering into exclusive distribution contracts, selling products below cost, acquiring other firms, and engaging in price discrimination are not questioned for firms without market power. But for firms with market power, these same practices are either per se illegal under the antitrust laws (e.g., tying under some conditions) regardless of its economic effects, or subject to a more extensive rule of reason inquiry (e.g., selling products below cost) into economic effects. The inquiry into market power is therefore central to many antitrust cases. ${ }^{46}$

Professional economists approaching the issue of market power in an industry in which static competition is the norm would ordinarily inquire into the existence of substitutes on the demand and supply sides and examine the extent to which these substitutes constrain the pricing ability of the firm or firms in question. They would also examine barriers to the entry of new

\footnotetext{
${ }^{45}$ In addition to monopolization cases, proof of significant market power is required of plaintiffs challenging vertical restraints other than resale price maintenance schemes, tying, and most non-cartel horizontal practices. Assam Drug Co. v. Miller Brewing Co., 798 F.2d 311, 315-16 (8th Cir. 1986) [hereinafter Assam Drug] (non-price vertical restraints; discusses similar rulings in the 5th, 6th, 7th, 9th, 11th and D.C. Circuits); Jefferson Parish Hospital District No. 2 v. Hyde, 466 U.S.2 13, 14 (1984) [hereinafter Jefferson Parish] (tying); K.M.B. Warehouse Distributors v. Walker Manufacturing, 61 F.3d 123 (2d Cir. 1995) [hereinafter K.M.B. Warehouse] (non-cartel horizontal practices; discusses similar rulings in several circuits). The "significant" qualifier is not always stated explicitly in antitrust inquiries but is always implied. The antitrust case law recognizes that most firms have at least some ability to charge prices in excess of marginal cost. See FTC v. Elders Grain, 868 F.2d 901, 907 (7th Circuit 1989); United States v. Realty Multi-List, 629 F.2d 1351, 1367-68 (5th Circuit 1980). Also the case law distinguishes between significant market power and monopoly power for some purposes. See Price (1989, pp. 190-200); Eastman Kodak v. Image Technical Services, 504 U.S. 451, 488 (1992); Reazin v. Blue Cross and Blue Shield, 899 F.2d 951, 966-67 (10th Circuit, 1990).

${ }^{46}$ The courts do not inquire into market power for agreements among competitors to fix prices or restrict output.
} 
suppliers and analyze the relationship between the prices being charged by the firms under consideration and their costs of production.

The courts and the enforcement agencies, however, have become fixated on market shares, and this has shaped the typical approach to market power analysis. This approach involves: (1) defining "the relevant market" in which the firms operate-with products and regions necessarily either 100 percent in or 100 percent out of the market; (2) calculating the share of the market thus defined for the firm or firms in question; and (3) inferring significant market power mainly from whether the share is high (60 percent is a favorite threshold for the courts). Even in old-economy industries in which production capacity is often important and market share tends to follow capacity, there is no rigorous defense for strict reliance on this approach to measuring market power. ${ }^{47}$ Elasticities of demand and supply fall along a continuum, as do cross-price elasticities of demand and supply. Thus there is no basis in economics for drawing hard market boundaries or for treating all products as either all in or all out of the market. ${ }^{48}$ Even if market definition is not a problem, a firm's ability to affect price generally depends on more than its share of current sales, as the courts have from time to time recognized. $^{49}$

\footnotetext{
${ }^{47}$ Nevertheless, calculating market shares may provide a useful screening device. If a firm has a small share of what we would all agree is a narrowly defined market, then one can reasonably conclude that it lacks market power. The market definition and market share calculations described in the Horizontal Merger Guidelines make sense so long as they are used mainly for this initial screening purpose. U.S. Department of Justice $(1997, \S 1)$.

${ }^{48}$ Fisher, McGowan, and Greenwood (1983, pp. 31-33); Schmalensee (1982, pp. 1798-1804); Schmalensee (1979, pp. 1004-1016); Fisher (1979, pp. 12-17).

${ }^{49}$ For example, consider United States v. General Dynamics Corp., 415 U.S. 486 (1974). The United States challenged the merger of two coal-mining companies that accounted for a large share of coal sales. The Court found that, for a variety of reasons, past coal production was a poor indicator of future competitive ability. Instead the Court looked at uncommitted coal reserves and concluded that there was insufficient evidence of a threat to competition.
} 
The market definition/market share approach to the analysis of market power is considerably more problematic for new-economy industries. In the new economy, today's sales and market share tend to be driven by the quality of today's products, perhaps amplified by network effects, not by durable assets like production capacity and distribution systems. Today's sales do not necessarily say anything about the value of intellectual capital, the quality or popularity of tomorrow's products, or the changing nature of the markets in which they will compete. Market positions based on intellectual property are fragile when innovation is rapid. There is an even more basic difficulty: leaders in high-technology industries must have (temporary) market power if there is to be dynamic competition that enhances consumer welfare. And, of course, the purpose of market definition and market power analysis is to learn to what extent competitive forces constrain the ability of a firm or set of firms to engage in actions that will harm consumers. ${ }^{50}$

\section{B. Defining Markets in New-Economy Industries}

Traditional market definition analysis, which studies constraints on firms' price/output decisions, can present a seriously misleading picture of competitive relations in the new economy. Successful incumbents in Schumpeterian industries are constrained primarily by dynamic competition: by the threat that another firm will come up with a drastic innovation that causes demand for the incumbent's product to collapse. The new product may be just a vastly better version of the old product (the Palm Pilot vs. the Apple Newton), or it may be an entirely different product that eliminates the demand for the old product (the hand-held calculator vs. the

\footnotetext{
${ }^{50}$ Evans (2001a); Lopatka and Page (1999).
} 
slide rule). ${ }^{51}$ These threats force new-economy firms to invest heavily in R\&D and to bring out new versions of their products - including versions that lead to the demise of their old versions. (For instance, Windows 95 largely_though not instantly_eliminated the demand for MS-DOS.) These threats also generally constrain the prices charged by incumbents: the higher the current prices and the smaller the network of users, the more attractive an entrant will be to consumerseven if incumbents lower prices in response to entry. ${ }^{52}$

The recent history of high-technology industries demonstrates that dynamic competition takes place among firms that are not necessarily competitors in the static markets that economists ordinarily define for antitrust cases. Dynamic competition has been particularly evident in the software industry. In some instances firms race to create an entirely new product category. For example, VisiCalc defined the category of spreadsheet software and was the early market leader. But it was eventually displaced, first by Lotus 1-2-3 and subsequently by Microsoft Excel. In other instances, dynamic competition takes the form of innovation to displace a category leader. For example, Micropro's WordStar was the early leader in word processing software for PCs, which significantly displaced dedicated word processing systems such as those offered by Wang. But WordStar was eventually displaced by WordPerfect. WordPerfect retained category leadership for approximately six years before being displaced by Microsoft Word, which was helped in part by the transition to graphical user interfaces and, in particular, Windows. ${ }^{53}$

This pattern is not unique to computer software. It can also be observed in other industries such as pharmaceuticals and handheld devices. For example, in 1977, SmithKline-

\footnotetext{
${ }^{51}$ Of course the distinction between "vastly better" and "entirely different" cannot be defined rigorously in general and is often a matter of judgment in particular cases.

${ }^{52}$ Fudenberg and Tirole (2000).

${ }^{53}$ See generally, supra note 31.
} 
Beecham offered the first $\mathrm{H}_{2}$-antagonist anti-ulcer drug, called Tagamet. ${ }^{54}$ When

GlaxoWellcome entered the market in 1983 with Zantac, it quickly took market share from Tagamet. Merck (Pepcid) and Eli Lilly (Axid) also entered the market eventually. By 1988, Zantac surpassed the market share of the first mover, Tagamet. By 1993, Zantac had 55 percent of the market, Tagamet had 21 percent, Pepcid had 15 percent, and Axid had 9 percent.

The race to develop operating systems for personal digital assistants (PDAs) is another example of dynamic competition. Apple introduced the first handheld PDA, called the Newton, in 1993, but that product was not a success with consumers. ${ }^{55}$ Following the failure of the Newton, a number of firms began developing operating system software for PDAs. In 1996, there were at least six firms with operating systems for these handheld devices either available to consumers or in development. ${ }^{56}$ By 1998 , the Palm OS was the clear leader in the PDA segment with a 73 percent share. ${ }^{57}$ Palm remains the category leader today, but its leadership faces threats from Microsoft's Windows CE operating system and Symbian's operating system, among others. $^{58}$

In new-economy industries, an essential element of market power analysis is an examination of actual and potential innovative threats to leading firms. ${ }^{59}$ This cannot be a simple exercise in drawing boundaries and computing shares or even looking at traditional barriers to

\footnotetext{
${ }^{54}$ Berndt, Pindyck, and Azoulay (2000).

${ }^{55}$ Carlton (1998, pp. 230-239).

${ }^{56}$ International Data Corporation (1998, Table 10).

${ }^{57}$ International Data Corporation (2000a, Table 1). Palm is a vertically integrated hardware-software vendor for PDAs although it recently licensed its PalmOS to competing hand-held device vendors.

${ }^{58} I d$. Microsoft and Symbian license their operating systems to hardware manufactures such as Compaq.

${ }^{59}$ As noted earlier (supra note 44), this is broadly related to the notion of "innovation markets." But as the discussion below indicates, it is important in the assessment of dynamic competition to look for competitive threats from alternative technologies.
} 
entry, which concern non-innovative entry. It generally involves the exercise of judgment regarding the likelihood of future races for market dominance and the likely nature of those races. There is no guarantee that such races will continue in any new-economy industry, but neither does the absence of a visible race at any particular point in time (e.g., after WordPerfect attained clear leadership in word processing) imply that dynamic competition is at an end. Examination of innovative threats also generally involves consideration of competitive threats based on technologies and design approaches that differ radically from those used by the incumbent. A useful examination of Wang's position in word processing in the early 1980s, for instance, would have been seriously misleading if it had not at least considered the emerging threat posed by personal computers. ${ }^{60}$

\section{The Relevance of Market Power in New-Economy Industries}

Static market power, usually measured by market share, has been used by the courts as a screen to enable them to avoid inquiring into antitrust claims when consumer harm is implausible and to focus scarce judicial resources on those situations in which market forces may not provide sufficient discipline ${ }^{61}$ But static market power, even if measured accurately by market share, is not a useful antitrust concept in high-technology industries, for two related reasons.

First, market share tests do not provide a useful screen in new-economy industries, since most leading firms have market power in the static sense. Thus a consistent application of this approach would imply that their business practices would always be subject to full-blown rule-

\footnotetext{
60 "Simple Formula for Success," Security Management, May 2000; Haley (1999); Hoard (1982).

${ }^{61}$ See, e.g., Arthur (1999, pp. 621-622); Klein (1999, pp. 57-58); Kauper (1997, pp. 1685-1686); ABA Section of Antitrust Law (1997); Monroe (1996, pp. 436-438); Arquit (1992); Assam Drug (supra note 45); Jefferson Parish (supra note 45); K.M.B. Warehouse (supra note 45).
} 
of-reason inquiries. Indeed, in many high technology industries a single firm has a high share of whatever category it serves; this category is a market under the approaches ordinarily used by the enforcement agencies in antitrust inquires. ${ }^{62}$ For example, Table 3 reviews the shares of leading high-technology companies in categories that plaintiffs could plausibly identify as markets in antitrust cases. Given the historic fragility of market leadership positions in new-economy industries, there is no economic basis for treating leading firms in these industries as if they had the sort of durable market position that would be associated with, for instance, large shares of steel-making or oil-refining capacity.

The second, related problem with reliance on market share in new-economy industries is that static market power does not provide a useful measure of the constraints that market forces place on efforts by a firm to take anticompetitive actions - those that will tend to reduce consumer welfare. In most traditional businesses, firms are primarily constrained by their direct competitors in the market. In some cases, potential competitors are also an important constraint because it is easy to enter the business, produce comparable products, and compete effectively. R\&D efforts are comparatively modest, and innovation is likely to result in incremental change, not "creative destruction." In many new-economy industries, on the other hand, leading firms are constrained mainly by rivals — known and unknown — that are investing or easily could invest in drastic innovations. They are not constrained much by the pricing or production decisions of existing firms, because they typically face few if any contemporaneous rivals, and scale

\footnotetext{
${ }^{62}$ The Federal Trade Commission and the U.S. Department of Justice have come to use the Horizontal Merger Guidelines to define markets in Sherman Act cases; see United States v. Visa U.S.A. et al., 98 CIV. 7076, Plaintiff's Trial Brief, June 10, 2000, p. 19; United States v. Microsoft Corp., No. 98-1232 [hereinafter U.S. v. Microsoft], Direct Testimony of Frederick R. Warren-Boulton, November 18, 1999, § IV.A.2; In re: Intel Corp. No. 9288, Complaint Counsels' Pretrial Brief (Public Version), February 25, 1999, § III.A. The Guidelines, however, provide numerical rules of thumb that help the enforcement agencies screen out clearly unobjectionable mergers and enable the parties to predict the likelihood of having to provide detailed justifications for a proposed 
economies and network effects are often effective barriers to the entry of comparable (or "metoo") products.

As a result, a proper market-power inquiry in new-economy industries must include a serious analysis of the vigor of dynamic competition. This requires looking beyond current sales figures. It is important, for instance, to examine ownership of and investment in relevant intellectual property—which may involve technologies not currently in commercial use. If, for instance, the current market leader owns all intellectual property necessary for radical innovation, dynamic competition will not be effective. Similarly, foreclosing rivals from important distribution channels is likely to restrain dynamic as well as static competition. ${ }^{63}$ If, on the other hand, several firms are making significant $R \& D$ investments in order to obtain or retain leadership positions, and if knowledgeable observers consider the outcome of the struggle to be in doubt, dynamic competition is likely to be healthy regardless of current market shares.

Similarly, the ability of new firms to enter into dynamic competition can impose significant constraints on the behavior of current market leaders. In sectors where capital requirements are small and the supply of skilled labor is deep—software and Silicon Valley come to mind — this constraint is likely to be particularly important. In other sectors, intellectual property positions or capital requirements may rob potential entrants into dynamic competition of any competitive force. At base, these are empirical questions that cannot be reliably answered by formulaic analysis.

\section{(...continued)}

merger. In the context of Sherman Act litigation, however, strict application of the merger guidelines tends to exclude relevant forms of competition and inflate market shares, thereby overstating the extent of market power.

${ }^{63}$ Thus while the effects of Microsoft's actions on the ability of others to distribute their wares was an issue in United States v. Microsoft Corp., the debate was primarily about facts, not about standards for illegal conduct. 


\section{Market Definition, Market Power, and the Microsoft Case}

In United States v. Microsoft Corp., the government claimed that Microsoft tried to prevent Netscape and Sun from producing software that could evolve into competition for Microsoft Windows. Microsoft allegedly invested in harming these potentially competitive products through a predatory campaign involving hundreds of millions of dollars of direct costs and foregone revenues. In order to see whether Microsoft's conduct was likely to harm consumers on balance - the key economic question in most antitrust analysis - it would be necessary to consider the extent to which Microsoft faced Schumpeterian competition from Netscape, Sun, and other firms with new technologies. It would also be necessary to examine whether Microsoft could have plausibly believed that eliminating Netscape and Sun as threats would free it from competition long enough to permit it to recoup an investment in predation. ${ }^{64}$

The government, following antitrust tradition, focused on static market power, using a market share approach based on the Horizontal Merger Guidelines. It defined a market for operating systems for Intel-compatible personal computers and found no current competitors able to prevent Microsoft from charging more than "the competitive price." ${ }^{\prime 65}$ The government also stressed Microsoft's persistently high share of this "market," the importance of network effects that would make it hard for equivalent competing operating systems to enter, and the fact that Microsoft charged different computer manufacturers slightly different prices for Windows. There was in fact no controversy between the government and Microsoft over whether Microsoft had static market power and, like any successful software firm, the ability to set price well above

\footnotetext{
${ }^{64}$ As we discuss below, without such a belief the alleged predation would be irrational.

${ }^{65}$ When asked what the competitive price of Windows 98 should be, an economist who testified for the government answered, "significantly below whatever it is" (U.S. v. Microsoft (supra note 62), Trial Testimony of Frederick Warren-Boulton, November 19, 1998, A.M. Session, p. 40). No other definition was ever offered.
} 
marginal cost. ${ }^{66}$ Microsoft argued that network effects in general offer no protection against dramatic innovations, which have occurred frequently in personal computer software, and that because price discrimination is common in both the old and new economies, it says little about the presence of substantial market power.

Unfortunately, this focus on static market power prevented a serious discussion of the role of dynamic competition. The government's market definition excluded the competitive threats—-Netscape's Navigator and Sun's Java — that allegedly led Microsoft to engage in predation because they were not operating systems for Intel-compatible computers. For the analysis of static competition, this was the right answer, since they were in fact not competing head to head with Windows as operating systems. For the more relevant analysis of dynamic competition, this definition was not useful, since both Navigator and Java were viewed by all the parties involved as having the potential not just to take some business away from Windows at the margin but to replace it swiftly as the leading software platform — in Marc Andreessen's memorable phrase, to reduce Windows to "a mundane collection of not entirely debugged device drivers....,67

We are not contending that it was obvious that Microsoft was constrained by the forces of dynamic competition. The analysis of dynamic competition is rarely simple, and one can legitimately debate how vulnerable Windows' market position was to drastic innovation. Rather, our point is that the government and its economists did not engage in that critical empirical

\footnotetext{
${ }^{66}$ See, e.g., U.S. v. Microsoft (supra note 62), Trial Testimony of Richard Schmalensee, January 20, 1999, P.M. Session, pp. 63-66.

${ }^{67}$ Marc Andreessen, quoted in Metcalfe (1995); see also Cusumano and Yoffie (supra note 33, p. 105).
} 
debate. The district court, following old-economy precedents, agreed that static market power was sufficient for a finding of monopoly. ${ }^{68}$

If antitrust is to benefit consumers, in litigation involving industries in which competition has centered on investment in intellectual property both sides should be able to stipulate that the firms have static market power. It should be understood that if dynamic competition is healthy, static market power is largely irrelevant for the purpose for which market power is considered in most antitrust cases, particularly those involving charges of monopolization: it does not provide an effective screen, and it does not summarize the relevant behavioral constraints. Thus, antitrust litigants dealing with the new economy should be obliged to offer and defend logically consistent descriptions of the current and likely future health of dynamic competition. A Schumpeterian past does not guarantee a Schumpeterian future, but it does provide relevant information.

\section{PREDATION}

\section{A. Legal Standards for Predation}

Until the early 1980s predatory pricing cases were often a defendant's nightmare. In such cases, defendants are charged with maintaining monopoly (or market dominance) by lowering price temporarily to prevent the entry or force the exit of a troublesome rival or set of rivals. It is generally irrational not to cut price in the face of new competition, but price cuts large enough to be effective might open the door to lawsuits. Lacking economic standards, judges and juries came to rely on evidence of injury and intent to determine whether or not price cuts were predatory. Thus a large firm's price cut that harmed a smaller rival, even a rival with much

\footnotetext{
${ }^{68}$ U.S. v. Microsoft (supra note 62), Court's Findings of Fact, November 5, 1999, 19 33-67, especially $\uparrow \uparrow$ 59-60.
} 
higher costs, might be found illegal, particularly if some salesman had written a memo about "crushing those upstarts" or something of the sort.

Areeda and Turner (1975) noted that the then-existing state of predatory pricing law served to harm consumers by discouraging competitive price reductions. They suggested using the relationship between price and average variable cost as a screen for predation. When firms charge prices below this level they are losing money, and predation is a possible explanation for this behavior. Under their test, firms can safely lower price in response to competition as long as price remains above average variable cost. ${ }^{69}$ This provides firms with a safe harbor within which they can engage in pro-competitive price-cutting.

Easterbrook (1981) took a different but complementary approach. He argued that predatory strategies were seldom likely to be profitable because of the difficulty of recouping the costs of eliminating competition, and that such strategies were therefore seldom tried. Thus, he contended, the application of cost-based predation tests was likely to harm consumers by deterring price-cutting while, since predation is rare, yielding few benefits. The Supreme Court reflected these concerns in its key modern decisions on this issue: Matsushita and Brooke Group. $^{70}$

The Court in Matsushita noted that predatory pricing is equivalent to an investment. For that investment to be rational, the firm or firms that engage in predatory pricing must expect to maintain monopoly power long enough to more than recoup the losses from the predatory pricing

\footnotetext{
${ }^{69}$ Joskow and Klevorick (1979) provide a useful discussion of the Areeda-Turner test and subsequent, related proposals.

${ }^{70}$ Matsushita Elec. Industrial Co. v. Zenith Radio Corp., 475 U.S. 574 [hereinafter Matsushita], 106 S. Ct. 1348,89 L. Ed. 2d 538 (1986); Brooke Group Ltd. v. Brown and Williamson Tobacco Corp., 509 U.S. 209 [hereinafter Brooke Group], 113 S. Ct. 2578; 125 L. Ed. 2d 168 (1993).
} 
campaign. ${ }^{71}$ The Court recognized, "For this reason, there is a consensus among commentators that predatory pricing schemes are rarely tried, and even more rarely successful." ${ }^{, 72}$ The Court concluded that in the case at hand, "The alleged conspiracy's failure to achieve its ends in the two decades of its asserted operation is strong evidence that the conspiracy does not in fact exist." ${ }^{, 73}$ Finally, the Court expressed great concern that false inferences of predation would "chill the very conduct the antitrust laws are designed to protect.",74

In Brooke Group, the Court required that plaintiffs establish that below-cost pricing had occurred and that the defendant had a reasonable expectation of recouping its predatory loses through future price increases. The Court's rationale for the recoupment test was that, even if below-cost pricing by a firm may hurt some of its rivals, if it is unable to recoup its losses, then aggregate market prices are lower, consumer welfare is enhanced, and the apparently predatory pricing scheme should not be condemned. ${ }^{75}$ In other words, even if there is harm to competitors, a court must be able to find harm to competition — and thus, ultimately, to consumers — in order to find an antitrust violation. ${ }^{76}$ The Brooke Group's recoupment test thereby sharply limited the

\footnotetext{
${ }^{71}$ Matsushita (supra note 70, at 588-589) ("The success of any predatory scheme depends on maintaining monopoly power for long enough both to recoup the predator's losses and to harvest some additional gain. Absent some assurance that the hoped-for monopoly will materialize, and that it can be sustained for a significant period of time, '[the] predator must make a substantial investment with no assurance that it will pay off." Citing Easterbrook (1981, p. 268).)

${ }^{72}$ Matsushita (supra note 70, at 589).

${ }^{73} I d$. at 592.

${ }^{74}$ Id. at 594.

${ }^{75}$ Brooke Group (supra note 70, at 224) ("Without [recoupment], predatory pricing produces lower aggregate prices in the market, and consumer welfare is enhanced. Although unsuccessful predatory pricing may encourage some inefficient substitution toward the product being sold at less than its cost, unsuccessful predation is in general a boon to consumers").

${ }^{76} I d$. at 225 ("Even an act of pure malice by one business competitor against another does not, without more, state a claim under the federal antitrust laws; those laws do not create a federal law of unfair competition or 'purport to afford remedies for all torts committed by or against persons engaged in interstate commerce." Citing Hunt $v$. Crumboch, 325 U.S. 821, 826 (1945).)
} 
situations in which defendants could be found guilty of predation when there was no prospect of harm to consumers. ${ }^{77}$

\section{B. Predation in New-Economy Industries}

The application of available predation tests to new-economy businesses is problematic in several respects. On the one hand, safe harbors based on variable costs provide new-economy firms with wide latitude for dropping prices for predatory or other reasons, since variable costs are often far below observed prices. On the other hand, penetration pricing, at or below variable cost, is common in many new-economy industries as a result of network effects. Software products, in particular, are often given away to build usage, increase demand for complementary products, and affect standards by firms that plainly lack monopoly power. Thus low_or even negative prices - may be rational and, so long as there is sufficient competition for the market, may be ultimately pro-competitive.

The most fundamental problems — which involve definition as well as measurementarise under winner-take-all competition. Suppose two firms, an incumbent (M) and an entrant (E), are engaged in a race to develop and attract lead users for the next-generation widget. And suppose, for simplicity, that whichever firm wins the race will have a permanent widget monopoly. It is clear that $\mathrm{M}$ might be able to use its position in the market to tilt this Schumpeterian race in its favor-by locking up all widget distribution channels in advance, for instance. It is equally clear that such practices, if they have substantial anticompetitive effects, are and should be illegal. But, as a logical matter, what sorts of behavior by $\mathrm{M}$ in the ongoing

\footnotetext{
${ }^{77}$ While the Brooke Group Court was obviously concerned with consumer welfare, its standard provides a useful screen - since "predation" without recoupment is very unlikely to harm consumers - not an exact test of welfare
} 
race should be condemned as predatory? And what practical test will detect such behavior without unduly discouraging pro-consumer competition?

Cost-based tests do not help in this context. How much would a non-predatory $\mathrm{M}$ be willing to spend on product development and attraction of lead users to win the race with E? If spending more guaranteed a win, $\mathrm{M}$ would be willing to spend up to the present value of the monopoly profits it would enjoy if it were to win. It would spend less if spending less would guarantee a win, but it would be better off walking away from the widget business than spending more. Of course, in the real world, it is uncertain who will win; monopolies do not last forever, and future profits can at best be roughly estimated. But the key point is that the maximum amount $\mathrm{M}$ would be willing to spend does not depend on whether it thinks predatory thoughts about E or not: an evil predator would not rationally spend more than the present value of future profits any more than a clean-thinking competitor. Thus, in principle as well as in practice, there is no cost-based test to distinguish predatory innovation (product development and marketing) from non-predatory innovation in a winner-take-all setting. Indeed, there is no logical difference between the two.

Neither does the Brooke Group recoupment test help under winner-take-all competition. ${ }^{78}$ Each firm in a winner-take-all race is likely to charge low prices, possibly even below variable cost, in the expectation that it will recoup its losses by raising prices once it wins the race. But it does not make any sense to define the predator as whoever wins the race. Moreover, consumers benefit from this sort of rivalry because firms enter the race and invest in losses early on.

\section{(...continued)}

improvement. We believe that complexities of dynamic analysis and difficulties of measurement make such an exact test unattainable. However, an exact test is not required to benefit consumers on balance.

${ }^{78}$ Brooke Group (supra note 70, at 224). 
Placing greater weight on evidence of intent, as in the days before Areeda-Turner (1975), would add heat, not light. In a winner-take-all race, the only alternative to failure is to destroy the competition and make money thereafter. Thus internal memos that brag about "keeping E out of the market" have exactly the same meaning as widely distributed press releases that brag about "providing a better widget than E and doing it faster."

Finally, the natural place to turn for an analysis of predation in dynamic competition is the discussion of "predatory innovation" by Ordover and Willig (1981). Under their proposed standard, the only such proposal in the scholarly literature of which we are aware, "the relevant question is whether the innovator anticipated positive incremental profit for the new product, given the continued viability of the rival." ${ }^{, 79}$ Unfortunately, this standard is generally unworkable. Key quantities, such as the expected future profit stream over time, are not observable, firms may invest in important new technologies without having detailed revenue forecasts, and the details of capital budgeting documents may not reflect top management consensus. We suspect its impracticality is one reason the Ordover-Willig test has not been embraced by the courts or by antitrust practitioners.

Moreover, under winner-take-all competition, the Ordover-Willig test has the same fundamental problem that robs cost-based and recoupment tests of any power: there is no nonexclusion standard of comparison that makes logical sense in a winner-take-all setting. If $\mathrm{M}$ wins the race to attract lead users, it obtains a monopoly and excludes E; if it loses, it is out of the

\footnotetext{
${ }^{79}$ Ordover and Willig (1981, pp. 29-30). For a finding of predation, they would also require that "the likelihood of the rival's exit must be substantially raised by the product introduction, and the additional monopoly profit that would accrue to the innovator after the exit of the rival must be sufficient to make the introduction of the new product profitable for the innovator" (p. 26).
} 
business, and its R\&D costs are money down a rat hole. Success, exclusion, and monopolization are one and the same.

Thus, under winner-take-all competition we not only lack useful tools for detecting predatory behavior, we do not have a good definition of such behavior. There would seem to be two possible ways for antitrust policy to respond while this remains true. First, judges could be instructed to engage in a full factual inquiry and to condemn as predatory dynamic competition that they find unreasonably intense or motivated by evil intent—-something like Justice Stewart's

approach to obscenity. ${ }^{80}$ The danger is that in the absence of clear standards, competition will be generally discouraged as firms try to limit antitrust risks, and consumers will be harmed. Second, judges could be instructed that if a defendant can establish that the relevant market is characterized by winner-take-all competition provides a complete defense against a charge of predatory behavior — and not, we hasten to add, against other possible antitrust charges. In light of the extraordinarily high costs of discouraging dynamic competition broadly, the second approach seems likely to produce a higher level of consumer welfare.

\section{Predation in the Microsoft Case}

Our primary focus here is not on the facts of the case, but rather on the test proposed by the government and ultimately adopted by the district court to support its finding of predation. Professor Franklin Fisher, testifying for the government, argued that a business action is predatory if it is profit-maximizing only because it creates market power by harming competition. There is no requirement under this test that losses be incurred or that price be below

\footnotetext{
${ }^{80}$ Jacobellis v. Ohio, 378 U.S. 184, 197 (1964) (Stewart, J., concurring).
} 
any measure of cost; the standard of comparison is not cost but maximum profit. ${ }^{81}$ The government offered no explicit analysis of either profitability or recoupment, as the Brooke Group standard would have required. The district court's finding of liability seemed to rest primarily on evidence that Microsoft spent money in the short run to compete with Netscape (and, to a lesser extent, Sun) and that internal emails described these actions as aimed at producing victory in winner-take-all competition. ${ }^{82}$

The first problem with this test is that it cannot be applied rigorously in practice. While one can, with some effort, compare revenues and costs quantitatively, a similar comparison of actual with maximum profits, particularly as both evolve over time under complex uncertainty, is plainly beyond the ability of economists and courts.

Second, we agree with Dennis Carlton and Jeffrey Perloff: "[T]he definition used by the government's economic witness of an anticompetitive act as one that isn't profit-maximizing absent the returns from increased monopoly profits is too stringent. If applied literally, it would

\footnotetext{
${ }^{81}$ As initially presented, Professor Fisher's definition seemed consistent with that of Ordover and Willig (1981): "The definition of a predatory anti-competitive act can be spelled out in two parts. The first part is deceptively simple: A predatory anti-competitive act is an act that is not expected to be profitable in the long run without accounting for the supra-normal profits that can be earned because of the adverse effects on competition. The second part of the definition is as follows. A predatory anti-competitive act is one that is expected to be profitable in the long run only when taking into account the supra-normal profits to be earned because of the adverse effects on competition." (emphasis in the original) U.S. v. Microsoft (supra note 62), Written Testimony of Franklin Fisher, ๆף 48-49. But it later became clear that Professor Fisher viewed departures from (his conception of) profitmaximization as "acts" to which the foregoing test was to be applied: "A predatory act, or an anticompetitive act, I should say, is an act that doesn't make sense except because of the monopoly rents to be earned when competition is driven out or hampered.... Well, one version is it's just a deliberate money-loser. A second version says, well, you don't charge the price you could have charged. ... If it wasn't for the possibility of destroying competition and earning monopoly rents, you would have charged a higher price and earned higher profits.... Actually, a seriously deep understanding of - well, I can't help it—of economics leads to the view that these are, in fact, the same thing properly considered." U.S. v. Microsoft (supra note 62), Direct (Rebuttal) Testimony of Franklin Fisher, June 1, 1999, AM Session, pp. 38-39.

82 Judge Jackson, the district court judge in United States v. Microsoft Corp., adopted Professor Fisher's test: "Because Microsoft's business practices 'would not be considered profit maximizing except for the expectation that ... the entry of potential rivals' into the market for Intel-compatible PC operating systems will be 'blocked or delayed,' Neumann v. Reinforced Earth Co., 786 F.2d 424, 427 (D.C. Cir. 1986), Microsoft's campaign must be termed predatory." U.S. v. Microsoft (supra note 62), Conclusions of Law, April 3, 2000, § I.A.2.c.
} 
prevent behavior that benefits consumers. ${ }^{, 83}$ Even in old-economy industries, Fisher's test could be used to attack above-cost pricing that had the effect of excluding less efficient entrants. Most businesses routinely invest in creating intellectual property, advertising, product differentiation, and other efforts. They do this because they expect to obtain market power- that is the only way they can be compensated for their efforts. And, particularly in new-economy industries with Schumpeterian competition, that market power frequently comes at the expense of existing or potential rivals. To prevent this behavior would plainly lower consumer welfare.

The Brooke Group test would not have been more illuminating. To see this, consider the world that would have existed if Microsoft had never developed a browser or competed with Netscape. Before introducing its Navigator browser in 1994, Netscape invested in creating a product that was better than the handful of existing browsers. ${ }^{84}$ It also invested in achieving “ubiquity.” In Marc Andreessen’s words:

The key to success for the whole thing was getting ubiquity on the [browser] side.... If you get ubiquity, you have a lot of options.... You can get paid by the product that you are ubiquitous on, but you can also get paid on products that benefit as a result. One of the fundamental lessons is that market share now equals revenue later, and if you don't have market share now, you are not going to have revenue later. Another fundamental lesson is that whoever gets the volume does win in the end. Just plain wins. ${ }^{85}$

\footnotetext{
83 "Carlton/Perloff Companion Web Site," available at $<$ http://occ.awlonline.com/bookbind/pubbooks/carlton awl/>.

${ }^{84}$ Clark (1999, pp. 149-150).

${ }^{85}$ Supra note 33, p. 24, quoting from Reid (1997, p. 31).
} 
This would seem to be a predatory strategy under the test proposed by the government and accepted by the district court. ${ }^{86}$ Netscape's strategy would be profitable only if it eliminated its rivals and thereby achieved dominance. This would also seem to be a predatory strategy, however, under the Brooke Group test: Netscape spent resources to distribute its browser for free (thus arguably selling below cost). It expected to make these losses back by using its "ubiquity" to sell complementary products for Web servers and later to receive revenues from its Internet portal site. Obviously, it could recoup its losses on the browser only if its "ubiquity" gave it market power over these complementary products.

\section{TYING}

\section{A. Current State of Tying Law}

Tying occurs when a firm makes the sale of one product conditional on the sale of a second product: generally, in order to purchase product A (the "tying" product), a buyer must also purchase product B (the "tied" product) from the same seller. The courts have considered tying by a firm that has market power over the tying product to be a per se violation of the antitrust laws (at least under some conditions) since the International Salt decision in $1947 .^{87}$ That is, the courts will not ordinarily entertain arguments (which would be legitimate in a ruleof-reason analysis) that tying results in consumer benefits in general or in the case at hand. As

\footnotetext{
${ }^{86}$ One could argue that this strategy would not come under the government's test because Netscape did not have market power at the time it entered the browser business. But it achieved a large share of that business very quickly and continued this basic strategy thereafter.

${ }^{87}$ International Salt Co. v. United States, 332 U.S. 392 (1947).
} 
one court said in 1949, "tying agreements serve hardly any purpose beyond the suppression of competition."

Economists have long argued that the law's hostility to this practice does not serve consumers well. ${ }^{89}$ While tying can be anticompetitive under certain conditions, there is no theoretical or empirical basis for a judgment that it is always or often harmful, even when done by firms that have market power. ${ }^{90}$ Firms without substantial market power routinely tie — or, equivalently, bundle or integrate — products that could in principle be sold separately. ${ }^{91}$ Such firms must do this for efficiency-based reasons: because it reduces their costs, increases their demand, lowers transactions costs, or reduces heterogeneity in consumers' willingness to pay, ${ }^{92}$ thus increasing profits. Although economists have identified circumstances under which tying could harm consumers on balance, as we discuss below, the court's tying prohibitions do not focus on these circumstances. ${ }^{93}$

In the last twenty years, jurists have increasingly recognized that the tying prohibitions implied by International Salt are far too sweeping. In her concurring opinion in the 1984 Jefferson Parish decision, for instance, Justice O'Connor wrote, "Unless it is to be illegal to sell cars with engines or cameras with lenses, this analysis [of what ties are illegal] must be guided by some limiting principle." 94 Unfortunately Justice Stevens, writing for the majority, declined to take issue with the fundamental problem: "It is far too late in the history of our antitrust

\footnotetext{
${ }^{88}$ Standard Oil Co. v. United States, 337 U.S. 293, 305 (1949).

${ }^{89}$ Bork (1978, pp. 365-381); Posner (1976, pp. 171-184). For a general summary of the debate surrounding the effects of tying arrangements, see Hylton and Salinger (2000).

${ }^{90}$ Carlton and Waldman (2000); Nalebuff (1999); Farrell and Katz (1998); Whinston (1990).

${ }^{91}$ Davis, MacCrisken, and Murphy (1998).

92 Bakos and Brynjolfsson (1999).

${ }^{93}$ Hylton and Salinger (supra note 89).
} 
jurisprudence to question the proposition that certain tying arrangements pose an unacceptable risk of stifling competition and therefore are unreasonable 'per se.",95

Ultimately, the Jefferson Parish decision was a largely unsuccessful attempt to put tying law on a sound footing. The majority enunciated a four-part test: (1) Is a substantial volume of commerce affected $?^{96}$ (2) Do two distinguishable product markets exist (based on distinct demands for two separate products) $?^{97}$ (3) Does the defendant have market power in the tying product market? ${ }^{98}$ (4) Does the arrangement involve the use of market power to force consumers to buy a product or service that they would not otherwise purchase? ${ }^{99}$ As the Jefferson Parish test has been interpreted, it condemns many ties to which there are no sound economic objections, and it fails to focus on those specific circumstances in which economists have identified possible anticompetitive effects from tying.

Lower courts have carved out an important exception to this test for "technological ties." The Fifth Circuit Court in Leasco held that findings of tying violations "must be limited to those instances where the technological factor tying the hardware to the software has been designed for the purpose of tying the products, rather than to achieve some technologically beneficial result." 100 To do otherwise, it held, would "enmesh the courts in a technical inquiry into the

\footnotetext{
(...continued)

${ }^{94}$ Jefferson Parish (supra note 45, at 34).

${ }^{95} I d$. at 14 .

${ }^{96} I d$. at 16.

${ }^{97} I d$. at 20.

${ }^{98} I d$. at 26.

${ }^{99} I d$. at 26 . The notion that any market transaction involves "forcing" consumers to buy is, of course, fundamentally problematic to economists.

${ }^{100}$ Response of Carolina, Inc. v. Leasco Response, Inc., 537 F.2d 1307 at 1330 (5th Cir. 1976) [hereinafter Leasco].
} 
justifiability of product innovations." ${ }^{101}$ Since Leasco, a number of other technological tying cases have established the courts' reluctance to intervene in product integration decisions. ${ }^{102}$ The Second Circuit Court in Foremost, for instance, held explicitly that the per se rule is inapplicable to technological ties. ${ }^{103}$ Areeda, Elhauge, and Hovenkamp argue that these precedents are consistent with a policy of questioning the technological merit of a tie only where there is: 1) genuine threat to the health of the allegedly tied complementary market; 2) substantial power in the allegedly tying primary market; 3 ) incompatibility between the redesigned product and the rival complementary products, and 4) no genuine dispute that the primary product design change lacks any technological benefit. ${ }^{104}$

\section{B. Tying, Bundling and Integration in New-Economy Industries}

The dynamic competitive process in new-economy industries often involves combining features and services that were previously available separately to create products that are differentiated from existing offerings. Such product integration can benefit consumers substantially even as it destroys markets for previously separate products.

Product integration has been a major force in the PC software industry over the last 20 years. Word processing software in the early 1980s, for instance, included neither spell checkers

\footnotetext{
${ }^{101} I d$.

${ }^{102}$ See, e.g., ILC Peripherals Leasing Corp. v. IBM, 448, 458 F. Supp. 228, 423 (N.D. Cal. 1978), aff'd sub nom.; In re IBM Peripheral EDP Devices Antitrust Litig., 481 F. Supp. 965 (N.D. Cal. 1979), aff'd sub nom.; Calif. Computer Prods., Inc. v. IBM, 613 F.2d 727 (9th Cir. 1979); Memorex Corp. v. IBM, 636 F.2d 1188 (9th Cir. 1980), cert. denied, 452 U.S. 972 (1981); Foremost Pro Color, Inc v. Eastman Kodak Co., 703 F.2d 534 (9th Cir. 1983), cert. denied, 465 U.S. 1039 (1984) [hereinafter Foremost] (The court rejected Foremost's tying claim on the ground that "any other conclusion would unjustifiably deter the development and introduction of those new technologies so essential to the continued progress of the economy.")

${ }^{103}$ Foremost (supra note 102, at 541-543).

${ }^{104}$ Areeda, Elhauge, and Hovenkamp (1996, ๆ 1757a).
} 
nor grammar checkers. Stand-alone products to perform each task were developed and sold: Borland's Turbo Lightning was a spelling checker, ${ }^{105}$ and Reference Software's Grammatik was a grammar checker. ${ }^{106}$ By the late $1980 \mathrm{~s}$, the leading word processing programs all included spelling checkers; ${ }^{107}$ by the early 1990 s, they all included grammar checkers as well. ${ }^{108}$ The market for the stand-alone products has now almost entirely disappeared. ${ }^{109}$ Similarly, modern spreadsheets, like Excel, QuattroPro, and 1-2-3, include graphing and optimization functionality that was formerly sold separately.

Integration is common in PC hardware as well, as math coprocessors illustrate. ${ }^{110}$ Intel's 16-bit and early 32-bit x86 microprocessors (8088/8086, 80286 and 80386 families) could perform integer but not floating point arithmetic. Floating point arithmetic could be done slowly in software or rapidly with separate math coprocessors sold by Intel and others; software developers had to write different versions of their products for computers with and without coprocessors. Intel's 80486 microprocessor (introduced in 1989) finally included both integer and floating point operations, though its $80486 \mathrm{SX}$ was essentially an 80486 without floating point capabilities. ${ }^{111}$ All of Intel's newer x86 microprocessors, starting with the Pentium in 1993, have included floating point operations. The demand for separate math coprocessors to work with x86 microprocessors has, accordingly, been completely eliminated.

\footnotetext{
${ }^{105}$ In a 1986 column in BYTE, Jerry Pournelle (1986) described his reliance on the product.

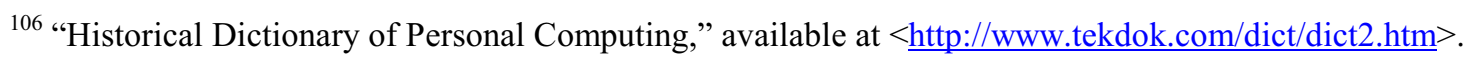

107 Seymour (1988).

108 Peterson (1994).

${ }^{109}$ Online searches for stand-alone spelling and grammar checkers found only a few niche products.

${ }^{110}$ Freedman (1996).

111 "Intel Corp., Microprocessor Hall of Fame", available at $<$ http://www.intel.com/intel/museum/25anniv/hof/hof main.htm $>$,
} 
Current examples of attempted integration include PDAs, such as those based on the Palm and Windows CE operating systems. Both of these operating systems have added (or soon will add) the capability, with suitable hardware, to play music files in the MP3 format. ${ }^{112}$ This integration may substantially reduce the demand for portable MP3 players. Another current area of integration involves PDAs and mobile phones. ${ }^{113}$

Product integration is, of course, not limited to the computer and consumer electronics industries. Take, for example, blood analyzers: Nova Biomedical, which has the largest share of sales of blood-gas analyzers to the point-of-care segment (e.g., emergency rooms), recently introduced its latest contribution to biotechnology, the BioProfile. The BioProfile analyzer incorporates eleven tests. The company advertises that "a single BioProfile analyzer replaces five or more analyzers and testing protocols, resulting in significant capital and labor savings." "114

Product integration of this sort is generally suspect under a strict reading of Jefferson Parish. The traditional, static approach to market analysis would typically find that the leading firm in most high-technology industries has market power-based mainly on having a high share of a narrowly defined product market. Consequently, as suggested by Table 3, most leading

(...continued)

$<$ http://www.intel.com/intel/museum/25anniv/hof/tspecs.htm>; "Intel Corp., Product Information," available at $<$ http://www.intel.com/intel/product/index.htm $>$ ?iid=headincy+product\& $>$.

112 "QuickSpecs: Compaq iPAQ Pocket PC H3600 Series," available at $<$ http://www5.compaq.com/products/quickspecs/10632_div/10632_div.HTML>; "Palm.com: Accessories," available at $<$ http://www.palm.com/software/addons.html $>$; Fried (2000).

113 "Palm Press Release, $3 \mathrm{Com}^{\circledR}$ and QUALCOMM Enter Strategic Alliance to Deliver Wireless Solutions for the Palm Computing ${ }^{\circledR}$ Platform," February 2, 1998, available at $<\underline{\text { http://www.palm.com/pr/qualcomm.html }>\text {; }}$ $<$ http://www.kyocera-wireless.com/pdq/pdqdetail benefits.htm>. See also Crothers (1999); "Palm Press Release, Motorola and Palm to Extend Palm User Experience into Mobile Phone Design," September 25, 2000, available at $<$ http://www.palm.com/about/pr/2000/092500.html>; "Microsoft Smart Phone Platform: Fact Sheet," September 2000, available at $<$ http://www.microsoft.com/presspass/events/fallcomdex00/docs/SmartPhoneFS.doc $>$; Miles (2000).

${ }^{114}$ Nova Biomedical company web site $<$ http://www.novabiomedical.com/biotech.htmll $>$. 
high-technology firms would fail the market-power screen in the Jefferson Parish test. If the leading firm, by product integration, "tied" the sale of another product for which there is currently separate demand to a product over which it would be found to have market power, it would fail the remaining prongs of the Jefferson Parish test.

In light of the ubiquity of competition and innovation via product integration in neweconomy industries, it may be reassuring that the "technology-tying" exception to Jefferson Parish seems to provide broad protection for this form of pro-consumer behavior. But the Supreme Court has not spoken on this issue, and the Microsoft case illustrates what could happen in many new-economy industries if the Supreme Court were to weaken or remove the technology-tying exception.

\section{Tying in the Microsoft Case}

As the rapid rise of the Internet became apparent, IBM announced in the fall of 1994 that it would include its Web browser (Web Explorer) in OS/2, and it did so in early 1995, more than six months before Windows 95 came out. Other vendors - including Apple (Cyber Dog) and Sun (HotJava) - also developed Web browsers to include with their operating systems. Microsoft, which was widely criticized for being slow to see the importance of the Internet, ${ }^{115}$ decided to include browsing software (later called Internet Explorer (IE)) in Windows 95, which was released in August 1995. Over the next several releases of IE, Microsoft integrated IE's browsing features and services more tightly into Windows and made them available to applications programs. ${ }^{116}$ All major operating systems currently include a Web browser "at no extra

\footnotetext{
${ }^{115}$ Supra note 33, p. 107.

${ }^{116}$ For example, a Web browser has to be able to understand Web addresses (URLs) and display HTML documents. Beginning with IE 3, Microsoft integrated these capabilities into Windows, so that other applications (not just (continued...)
} 
charge." ${ }^{117}$ As far as we have been able to verify, no vendor (except Microsoft) has ever offered separate versions of an operating system, with and without a Web browser. ${ }^{118}$

The Justice Department claimed in U.S. v. Microsoft that Microsoft's inclusion of IE in Windows was a per se illegal tie, and the district court agreed. The district court mentioned the technological tying cases and acknowledged the danger that a court could "improvidently wind up condemning 'integrations' that represent genuine improvements to software that are benign from the standpoint of consumer welfare and a competitive market." ${ }^{\prime 19}$ However, the district court concluded that it was bound by Jefferson Parish. Despite the D.C. Circuit's decision in a related case that the inclusion of IE in Windows involved technological integration, ${ }^{120}$ the district court also found that it was "not at liberty to extrapolate a new rule governing the tying of software products",121

(...continued)

Web browsing) could use these features. Microsoft also revamped the help system in Windows to take advantage of these features, thereby simplifying the work that application developers must do in order to create help files for their applications. Designing the operating system so that blocks of code that perform Web browsing functions also perform other functions for applications programs has obvious efficiencies, but this sort of code-sharing means that the code that enables Web browsing cannot be removed from Windows without disabling the system.

${ }^{117}$ Microsoft Corporation, "Microsoft Windows 98 Product Guide: About the Features," December 3, 1998; "Apple - Mac OS - Features: For All Your Work, Mac OS 8.5 Comes with the Works," Apple Computer, Inc., 1998; Mauro, Jim, "Solaris 7 Arrives," SunWorld, November 1998; "Caldera OpenLinux 1.3 Product Information," Caldera Systems, Inc., 1998; "Official Red Hat 5.1 Linux Operating System Installation Guide," Red Hat Software Inc., 1998, p. 228; "DR-DOS Overview," Caldera, Inc., 1998; Be, Inc., "The BeOS Virtual Tour, BeOS Release 3," 1998, available at $<$ http://www.be.com/products/beos tour/screen4.html $>$; "Partial Microsoft Response to Written Testimony by Government Witness John Soyring," PR Newswire, November 17, 1998; "UnixWare 7 New Features Guide," SCO, 1998.

${ }^{118}$ For further discussion, see Evans, Nichols, and Schmalensee (supra note 5).

${ }^{119}$ He cited three technological tying cases, Foremost (supra note 102, at 542-43); Leasco (supra note 100, at 1330); Telex Corp. v. IBM Corp., 367 F. Supp. 258, 347 (N.D. Okla. 1973).

${ }^{120}$ United States v. Microsoft Corp., 980 F. Supp. 537 (D.D.C. 1997), rev'd, 147 F.3d 935 (D.C. Cir. 1998) [hereinafter U.S. v. Microsoft II]; See Evans, Nichols, and Schmalensee (supra note 5) and Hylton and Salinger (supra note 89) for a detailed discussion of the case.

${ }^{121}$ For more detailed discussion see Evans, Nichols, and Schmalensee (supra note 5). 
The district court's application of the Jefferson Parish test was beset with some problems that the test has in all industries — whether high-technology or not. As mentioned above, that test does not measure consumer benefits and costs or embody any theory of how tying could harm consumers. It thus cannot indicate whether any challenged tie is likely to reduce consumer welfare.

At least as interpreted by the district court, the Jefferson Parish test did not require examination of the demand for a version of Windows without a browser, though such an examination is necessary for any analysis of the effect of the tie on competition or consumer welfare. ${ }^{122}$ In fact, as noted above, as a result of the district court's injunction in a related matter, ${ }^{123}$ Microsoft had licensed a version of Windows 95 that had IE disabled. Only one OEM, Packard Bell/NEC, chose that version, and only for two of its laptop computer lines. ${ }^{124}$

The district court's analysis also exemplifies the problems of using Jefferson Parish to evaluate product design in high-technology industries. As discussed above, dynamic competition in these industries involves the steady accretion of features and services in products. Much of the past 25 years of innovation in these industries could be found illegal under the Jefferson Parish test as applied by the district court. Many new-economy firms have static market power and have integrated features or services previously sold as separate products. Just as one could not buy Windows without a Web browser, one could not get WordPerfect without a spellchecker, an Intel Pentium processor without floating point processing capabilities, a version of the Mac OS 8.5

\footnotetext{
${ }^{122}$ The district court did assert that some consumers would prefer an operating system with no browser (e.g. some corporate users or users that have no desire to browse the Web), but it did not assert that this demand is substantial. Supra note 68, ๆๆ 151-152.

${ }^{123}$ U.S. v. Microsoft II (supra note 120).

${ }^{124}$ Deposition of Jon Kies, transcribed in U.S. v. Microsoft (supra note 62), December 16, 1998, A.M. Session, pp. $5-7$.
} 
without sophisticated file-searching capabilities, ${ }^{125}$ an Apple Macintosh computer without the Macintosh operating system, or a Nova Biomedical BioProfile blood analyzer that performed only a single test. Similarly, the district court's analysis would have condemned Microsoft for adding to MS-DOS over time such features as memory management, disk caching, file management, a full-screen text editor, hard-disk recovery utilities, and file undelete features_-all of which had been sold as stand-alone applications by independent software vendors.

Most of the trial testimony on the tying issue in the Microsoft case concerned whether Windows and IE were separate products and whether it was possible to separate Windows and IE without "breaking" Windows. On appeal, the government ultimately argued that Microsoft engaged in an illegal tie because it failed to offer a version of Windows in which consumers were barred from direct access to the IE features that were included in Windows - much like requiring automobile makers to sell cars with radios that consumers cannot use. ${ }^{126}$ Legal scholars may find disputes of this sort intellectually stimulating. Economists understand that they do not help determine whether the competitive behavior at issue helps or harms consumers.

\section{CONCLUSIONS}

Despite a few cases that might suggest otherwise, antitrust operates more as a system of deterrence than as a system of regulation. It shapes economic behavior by attaching legal risk to certain forms of conduct under certain conditions. A classic problem in the design of antitrust policy is how to deter conduct that is anti-competitive and welfare-reducing, while not

\footnotetext{
125 “Apple Introduces Mac OS 8.5--The Must-Have Upgrade,” Apple Computer, Inc. press release, October 14,

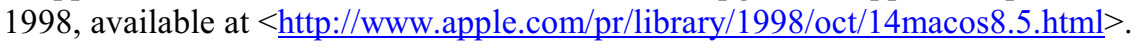

${ }^{126}$ United States v. Microsoft Corp., Nos. 00-5212, 00-5213, Brief for Appellees United States and State Plaintiffs, January 12, 2001, § III.B.1. Note that consumers have indirect access to these features when they are used by applications programs - for instance, when Intuit's Quicken "goes to the Web."
} 
discouraging the very pro-competitive, welfare-enhancing competition that antitrust is designed to protect. This classic problem persists in new-economy industries.

Firms with market power may be able to take actions that substantially reduce competition and consumer welfare in the long run, and new-economy firms may possess substantial market power. In deciding whether they do, however, it is logically necessary for courts to focus explicitly on the vigor of dynamic competition. Static market definition/market share analysis will not shed light on this issue, nor will a simple listing of past innovations. The past vigor of dynamic competition does not determine its present and future health, though it does provide useful information. Unlike price/output decisions, analysis of dynamic competition requires evidence about, among other things, the pattern of investment in developing new products (and complements thereof), the control of critical assets (particularly intellectual property and distribution channels), and the beliefs (preferably as revealed by behavior) of market participants and informed observers about the nature and pace of innovation.

In particular, the analysis of market power in new-economy industries must consider the vulnerability of leading firms to entry powered by drastic innovation, not just to the entry of firms producing equivalent products with known processes. Analysis of this sort of fragility may require difficult judgments about the likelihood of disruptive innovations in the future, but simply to assume such innovations cannot occur is to ignore history and to impart substantial and obvious bias to market power analysis in important sectors.

There are many things, such as price fixing, merger to monopoly, or foreclosure of essential distribution channels, that new-economy companies with substantial market power could in principle do to reduce competition. Such conduct is and should be illegal, as it is in 
traditional industries. But economically sound analysis of some other aspects of business behavior must take into account important features of new-economy industries.

Testing for predation is difficult in old-economy industries, as the Supreme Court recognized in Matsushita (televisions) and Brooke Group (cigarettes). Unless the courts are extremely careful, it is very easy to condemn intense competition that ultimately benefits consumers. This danger is much greater in Schumpeterian industries. Indeed, we have argued that there is no test for predatory conduct in winner-take-all situations that will not have as its main effect discouraging welfare-enhancing competition. We are thus led to the conclusion that the demonstration of healthy dynamic competition that has important winner-take-all characteristics should be a defense to claims of predation. Lacking a defensible test, the only alternative is to throw the door open in new-economy industries to decisions driven by debates about whether defendants intended to exclude, to compete, or merely to survive- even though these are logically indistinguishable—and undisciplined by serious economic analysis.

Similarly, analysis of tying claims in new-economy industries must consider the ubiquity of integration as a competitive strategy and the extreme risk of having judges and juries secondguess product design decisions. We believe the deference shown to those decisions by appeals courts in the technological tying decisions cited above will serve consumers far better than application of the Jefferson Parish test to product integration decisions in new-economy industries. 


\section{REFERENCES}

ABA Section of Antitrust Law, Antitrust Law Developments, $4^{\text {th }}$ ed, 1997.

Ahlborn, Christian, David S. Evans, and Atilano Jorge Padilla, “Competition Policy on Internet Time: Is European Competition Law Up to the Challenge?" European Competition Law Review, Issue 5, May 2001.

Areeda, Philip, Antitrust Law, Vol. IX, Boston: Little, Brown and Company, 1991.

Areeda, Philip, Einer Elhauge, and Herbert Hovenkamp, Antitrust Law, Vol. X, Boston: Little, Brown and Company, 1996.

Areeda, P. and D. Turner, "Predatory Pricing and Related Practices under Section 2 of the Sherman Act," Harvard Law Review, Vol. 88, 1975, pp. 697-733.

Arquit, Kevin J., "Market Power in Vertical Cases," Antitrust Law Journal, Vol. 60, 1992, p. 921.

Arthur, Thomas C., "Formalistic Line Drawing: Exclusion of Unauthorized Servicers from Single Brand Aftermarkets Under Kodak and Sylvania," Iowa Journal of Corporate Law, Vol. 24, 1999, p. 603.

Baer, William J., and David A. Balto, “Antitrust Enforcement and High-Technology Markets,” Michigan Telecommunications Technology Law Review, Vol. 5, 1998/1999, p. 73.

Bakos, Yannis and Erik Brynjolfsson, "Bundling Information Goods: Pricing, Profits, and Efficiencies," Management Science, Vol. 45, No. 12, 1999.

Becker, Gary S., Human Capital: A Theoretical and Empirical Analysis, With Special Reference to Education, 2nd Ed., New York: National Bureau of Economic Research, Columbia University Press, 1975. 
Berndt, Ernst R., Robert S. Pindyck, and Pierre Azoulay, “Consumption Externalities and Diffusion in Pharmaceutical Markets: Antiulcer Drugs,” NBER Working Paper No. 7772, 2000.

Besen, Stanley and Joseph Farrell, "Choosing How to Compete: Strategies and Tactics in Standardization," Journal of Economic Perspectives, Vol. 3, No. 2, 1994, p. 117.

Bork, Robert H., The Antitrust Paradox: A Policy At War With Itself, New York: The Free Press, 1978.

Carlton, Dennis W., “Antitrust Policy Toward Mergers When Firms Innovate: Should Antitrust Recognize the Doctrine of Innovation Markets?” Testimony before the Federal Trade Commission Hearings on Global and Innovation-based Competition, October 25, 1995.

Carlton, Dennis W. and Michael Waldman, “The Strategic Use of Tying to Preserve and Create Market Power in Evolving Industries," George J. Stigler Center for the Study of the Economy and the State Working Paper \#145, March 2000; available at $<\underline{\text { http://gsbwww.uchicago.edu/research/cses/WorkingPapersPDF's/145.pdf }>}$.

Carlton, Jim, Apple, New York: HarperBusiness, 1998.

Clark, Jim, Netscape Time, New York: St. Martin’s Press, 1999.

Council of Economic Advisers, Economic Report of the President, Washington D.C.: United States Government Printing Office, 2000.

Crothers, Brooke, “IBM, Rivals Work to Keep Email Simple," CNet News.com, 1999, available at $<\underline{\text { http://news.cnet.com/news/0-3865-200-1421865.html }>\text {. }}$

Cusumano, Michael A. and David B. Yoffie, Competing on Internet Time: Lessons from Netscape and the Battle with Microsoft, New York: Touchstone Books, 1998. 
Davis, Steven J., Jack MacCrisken, and Kevin M. Murphy, "Integrating New Features into the PC Operating System: Benefits, Timing, and Effects on Innovation,” 1998, available at $<\underline{\mathrm{http}}$ ://www.neramicrosoft.com/NeraDocuments/Analyses/integrating.pdf $>$.

Easterbrook, Frank, "Predatory Strategies and Counterstrategies," University of Chicago Law Review, Vol. 48, 1981, p. 263.

Economides, Nicholas, “The Economics of Networks,” International Journal of Industrial Organization, Vol. 14, No. 6, 1996, pp. 673-99.

Evans, David S., "Dodging the Consumer Harm Inquiry: A Brief Survey of Recent Government Antitrust Cases," St. John's Law Review, Vol. 75, Issue 3, 2001 a. "Antitrust in the New Economy," Computer Industry Committee Newsletter, Section of the Antitrust Law, American Bar Association, Spring $2001 \mathrm{~b}$.

Evans, David S., Albert Nichols, and Bernard Reddy, "The Rise and Fall of Leaders in Personal Computer Software," NERA, 1999, available at

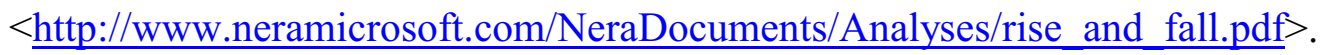

Evans, David S. and Bernard J. Reddy, "Some Economic Aspects of Standards in Network Industries and Their Relevance to Antitrust and Intellectual Property Law," in Intellectual Property Antitrust 1996, Practicing Law Institute, 1996.

Evans, David S., Albert L. Nichols, and Richard Schmalensee, “An Analysis of the Government's Economic Case in U.S. v. Microsoft," Antitrust Bulletin, Vol. 46, No. 2, Summer 2001.

Evans, David S. and Richard Schmalensee, "Be Nice to Your Rivals: How the Government Is Selling an Antitrust Case without Consumer Harm in United States v. Microsoft," in 
Evans, David S., Franklin M. Fisher, Daniel L. Rubinfeld, and Richard L. Schmalensee, Did Microsoft Harm Consumers? Two Opposing Views, Washington D.C.: AEI-

Brookings Joint Center for Regulatory Studies, 2000.

-------, "A Guide to the Antitrust Economics of Networks," Antitrust, Vol. 10, No. 2, 1996, p. 36.

FactSet Research Systems, Inc., CompuStat Monthly Database, 2001.

Farrell, Joseph and Michael L. Katz, "The Effects of Antitrust and Intellectual Property Law on Compatibility and Innovation," Antitrust Bulletin, Vol. 43, 1998, pp. 609-50.

Fisher, Franklin M., “Diagnosing Monopoly,” Southern Economic Journal, Vol. 45, No. 4, 1979, pp. 7-33.

Fisher, Franklin M., John J. McGowan, and Joen E. Greenwood, Folded, Spindled, and Mutilated: Economic Analysis and U.S. v. IBM, Boston: Charles River Associates, 1983.

Freedman, Alan, The Computer Desktop Encyclopedia, New York: Amacom, 1996.

Fried, Ian, "Palm and Microsoft Duke It Out at Comdex," CNet News.com, 2000, available at $<$ http://news.cnet.com/news/0-1006-200-3611466.html>.

Fudenberg, Drew and Jean Tirole, "Pricing a Network Good to Deter Entry," Journal of Industrial Economics, Vol. 48, No. 4, 2000, pp. 373-90.

Gans, Joshua S., David H. Hsu, and Scott Stern, "When Does Start-Up Innovation Spur the Gale of Creative Destruction?” NBER Working Paper No. 7851, 2000.

Gilbert, Richard J., "Symposium on Compatibility: Incentives and Market Structure," Journal of Industrial Economics, Vol. 40, No. 1, 1992, p. 1. 
Gilbert, Richard J. and David M.G. Newbery, "Preemptive Patenting and the Persistence of Monopoly," American Economic Review, Vol. 72, No. 3, 1982, pp. 514-525.

Gilbert, Richard J. and Steven C. Sunshine, "Incorporating Dynamic Efficiency Concerns in Merger Analysis: The Use of Innovation Markets,” Antitrust Law Journal, Vol. 63, 1995a, p. 569.

Gilbert, Richard J. and Steven C. Sunshine, "The Use of Innovation Markets: A Reply to Hay, Rapp, and Hoerner," Antitrust Law Journal, Vol. 64, 1995b, p. 75.

Gookin, Dan, “Windows 3.1 vs. OS/2 2.0,” InfoWorld, 1992.

Grove, Andrew S., Only The Paranoid Survive, New York: Doubleday, 1996.

Haley, Colin C., "Dutch Firm's Buy of Wang Global Seen as Winner by All Parties," Mass High Tech, 1999.

Hay, George A., "Innovations in Antitrust Enforcement," Antitrust Law Journal, Vol. 64, 1995, p. 7.

Hoard, Bruce, "Wang Amasses Dominant Share of Cluster WP Market," Computerworld, 1982.

Hoerner, Robert J., "Innovation Markets: New Wine in Old Bottles?” Antitrust Law Journal, Vol. 64, 1995, p. 49.

Hylton, Keith and Michael Salinger, "Tying Law and Policy: A Decision Theoretic Approach" (mimeo), Boston University, 2000.

International Data Corporation, "Pocketful of PCs?” No. 22184, 2000a.

-------, “Server Operating Environments Market Forecast and Analysis, 2000-2004,” No. 22347, 2000b. 
-------, “Technology Road Map of Smart Handheld Devices,” No. 16225, 1998.

Jorgenson, Dale W., “Information Technology and the U.S. Economy,” Presidential Address to the American Economic Association, January 6, 2001.

Joskow, P. and A. Klevorick, “A Framework for Analyzing Predatory Pricing Policy," Yale Law Journal, Vol. 89, 1979, pp. 213-270.

Katz, Michael and Carl Shapiro, 1994, "Systems Competition and Network Effects," Journal of Economic Perspectives, Vol. 3, No. 2, 1994, p. 93.

-------, , "Network Externalities, Competition, and Compatibility,” American Economic Review, Vol. 75 , No. 3, 1985, pp. 424-440.

Kauper, Thomas E., "The Problem of Market Definition Under EC Competition Law," Fordham International Law Journal, Vol. 20, 1997, p. 1682.

Klein, Benjamin, "Distribution Restrictions Operate By Creating Dealer Profits: Explaining the Use of Maximum Resale Price Maintenance in State Oil v. Kahn," Supreme Court Economic Review, Vol. 7, 1999, p. 1.

Klein, Joel, Statement Before the Antitrust, Business Rights and Competition Subcommittee Committee on the Judiciary, United States Senate, March 22, 2000.

Lerner, Josh, "The Returns to Investments in Innovative Activities: An Overview and an Analysis of the Software Industry," Harvard Business School and NBER, 1998, available at $<$ http://www.neramicrosoft.com/NeraDocuments/Analyses/returns_to.pdf $>$.

Levin, Richard C., and Peter C. Reiss, "Tests of a Schumpeterian Model of R\&D and Market Structure," in Z. Griliches, ed., $R \& D$, Patents, and Productivity, Chicago: University of Chicago Press, 1984. 
Liebowitz, S.J. and S.E. Margolis, "Network Externality: An Uncommon Tragedy,” Journal of Economic Perspectives, Vol. 3, No. 2, 1994, p. 133.

Lopatka, John E. and William H. Page, “Antitrust on Internet Time: Microsoft and the Law and Economics of Exclusion," in E. Gellhorn and L. Ribstein eds, Supreme Court Economic Review, University of Chicago Press, 1999.

Mankiw, N. Gregory, Principles of Microeconomics, Fort Worth: Dryden Press, 1998.

Margolis, S.E. and S.J. Liebowitz, "Causes and Consequences of Market Leadership in Application Software," in Winners, Losers, \& Microsoft: Competition and Antitrust in High Technology, Oakland: Independent Institute, 1999.

Markoff, John, “Sales Seem Brisk As Windows 95 Hits the Shelves,” New York Times, 1995.

Metcalfe, Bob, "From the Ether: Without Case of Vapors, Netscape's Tools Will Give Blackbird Reason to Squawk," InfoWorld, 1995.

Miles, Stephanie, "Microsoft Abuzz Over Web-Enabled Cell Phone," CNet News.com, 2000, available at $<$ http://news.cnet.com/news/0-1006-200-2479539.html $>$.

Miller, Michael J., “OS/2 Warp and beyond,” PC Magazine, 1995a.

-------, "Your next operating system; comparison of Windows NT Workstation 3.51, Windows 95, Windows 3.1, Windows for Workgroups 3.11 and IBM OS/2 Warp Connect," PC Magazine, $1995 b$.

Monroe, Murray S., "Antitrust Symposium: Vertical Restraints," University of Toledo Law Review, Vol. 27, 1996, p. 433.

Nalebuff, Barry, "Bundling” (unpublished manuscript), 1999. 
National Science Foundation, Division of Science Resources Studies (NSF/SRS), Research and Development in Industry, Annual Report, 1969, 1981, 1992, and 1998.

Ordover, Janusz A. and Robert D. Willig, “An Economic Definition of Predation: Pricing and Product Innovation," Yale Law Journal, Vol., 91, 1981, pp. 8-53.

Peterson, W.E., Almost Perfect, Prima Publishing, 1994, available at $<\underline{\text { http://www.fitnesoft.com/AlmostPerfect/ }>\text {. }}$

Petreley, Nicholas, "Press missing big story: OS/2 to win desktop war over delayed Windows 95," InfoWorld, 1995.

Pitofsky, Robert, “Antitrust Analysis in High-Tech Industries: A 19th Century Discipline Addresses 21st Century Problems," Prepared Remarks for the American Bar Association Section of Antitrust Law's Antitrust Issues in High-Tech Industries Workshop, February 25-26, 1999.

Posner, Richard, “Antitrust in the New Economy," Address at Conference on Antitrust in New York sponsored by the American Law Institute-American Bar Association Committee on Continuing Professional Education, September 14, 2000, published in Tech Law Journal, available at $<$ http://www.techlawjournal.com/atr/-20000914posner.asp $>$.

--------, Antitrust Law: An Economic Perspective, Chicago: University of Chicago Press, 1976.

Pournelle, Jerry, “Computing at Chaos Manor: Jerry’s Best of 1985 Awards,” Byte, 1986, available at $<$ http://www.byte.com/art/9604/sec5/art2.htm $>$.

Price, Richard G., "Market Power and Monopoly Power in Antitrust Analysis," Cornell Law Review, Vol. 75, 1989, p. 190. 
Rapp, Richard T., "The Misapplication of the Innovation Market Approach to Merger Analysis," Antitrust Law Journal, Vol. 64, 1995, p. 19.

Reid, Robert H., Architects of the Web: 1,000 Days That Built the Future of Business, New York: Wiley, 1997.

Reinganum, Jennifer F., "The Timing of Innovation: Research, Development, and Diffusion," in Handbook of Industrial Organization, Amsterdam: North-Holland Press, 1989, pp. 849908.

--------, "Innovation and Industry Evolution,” Quarterly Journal of Economics, Vol. 99, 1985, pp. 81-99.

Rubinfeld, Daniel L., "Competition, Innovation, and Antitrust Enforcement in Network Industries," Address Before the Software Publishers Association 1998 Spring Symposium, March 24, 1998, available at $<\underline{\text { http://www.usdoj.gov/atr/public/speeches/1611.htm }>}$.

Schmalensee, Richard, “Antitrust Issues in Schumpeterian Industries," American Economic Review, Vol. 99, 2000, pp. 192-196.

--------, "Sunk Cost and Market Structure: A Review Article," Journal of Industrial Economics, Vol. 40, June 1992, pp. 125-134.

-------, “Another Look at Market Power,” Harvard Law Review, Vol. 95, 1982, p. 1789.

-------, "On the Use of Economic Models in Antitrust: The ReaLemon Case," University of Pennsylvania Law Review, Vol. 127, 1979, p. 994.

Schumpeter, Joseph A., Capitalism, Socialism, and Democracy, 3rd. Ed., New York: Harper, 1950. 
Seymour, Jim, “Fast, Flexible, \& Forward-looking,” PC Magazine, 1988.

Shepherd, Carl and Steven Payson, U.S. Corporate R\&D, Volume II, a report jointly prepared by the U.S. Department of Commerce/Office of Technology Policy and the National Science Foundation, Division of Science Resources Studies, NSF 00-302, Arlington, VA, 1999.

Sutton, John, Sunk Costs and Market Structure: Price Competition, Advertising, and the Evolution of Concentration, Cambridge: MIT Press, 1991.

Trimble, Tim and Chris DeVoney, "Win 95 bests OS/2 Warp," Computerworld, 1995.

U.S. Bureau of Labor Statistics, Department of Commerce, Current Population Survey Labor Extracts, Outgoing rotations (1997-1999).

U.S. Census Bureau, Department of Commerce, "Statistics for Industry Groups, 2000," Annual Survey of Manufactures, 2000, available at $<$ http://www.census.gov/prod/2000pubs/m98as 1.pdf $>$.

--------, “Semiconductor and Related Device Manufacturing, Industry Series, 1997,” 1997 Economic Census, 1999a, available at $<$ http://www.census.gov/prod/ec97/97m3344c.pdf $>$.

-------, "Pharmaceutical Preparation Manufacturing, Industry Series, 1997," 1997 Economic Census, 1999b, available at $<$ http://www.census.gov/prod/ec97/97m3254b.pdf $>$.

--------, “Comparative Statistics for United States," 1997 Economic Census, July 1999c, available at $<$ http://www.census.gov/epcd/ec97sic/e97sus.htm $>$.

U.S. Department of Justice and the Federal Trade Commission, Horizontal Merger Guidelines (revised April 8, 1997). 
Vickers, John, "The Evolution of Market Structure When There Is a Sequence of Innovations," Journal of Industrial Economics, Vol. 35, No. 1, 1986, pp. 1-12.

Waldman, Don E. and Elizabeth J. Jensen, Industrial Organization: Theory and Practice, Reading MA: Addison-Wesley, 1998.

Whinston, Michael D., "Tying, Foreclosure, and Exclusion,” American Economic Review, Vol. 80, 1990, pp. 837-59. 
Figure 1: Summary of Category Leaders for Microcomputer Software: Shares in Shipments by Leading Firms

Word Processors

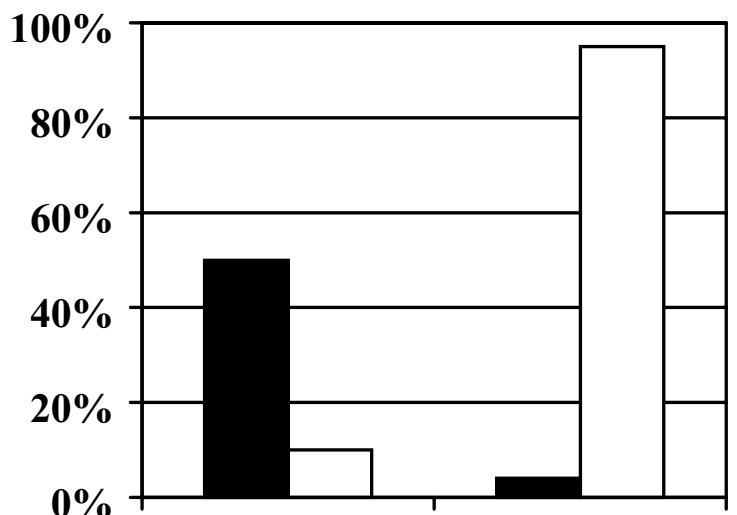

1990

1997

\section{WordPerfect}

$\square$ Microsoft Word

Personal Finance

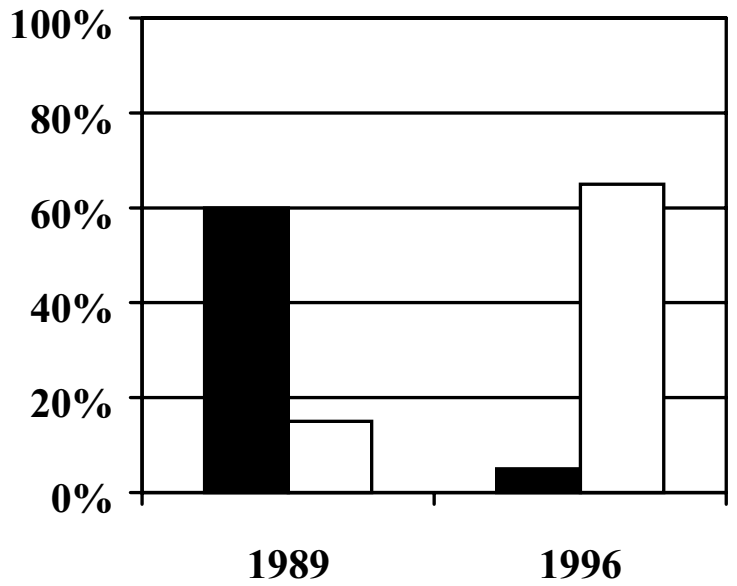

Managing Your Money $\square$ Quicken

Spreadsheets

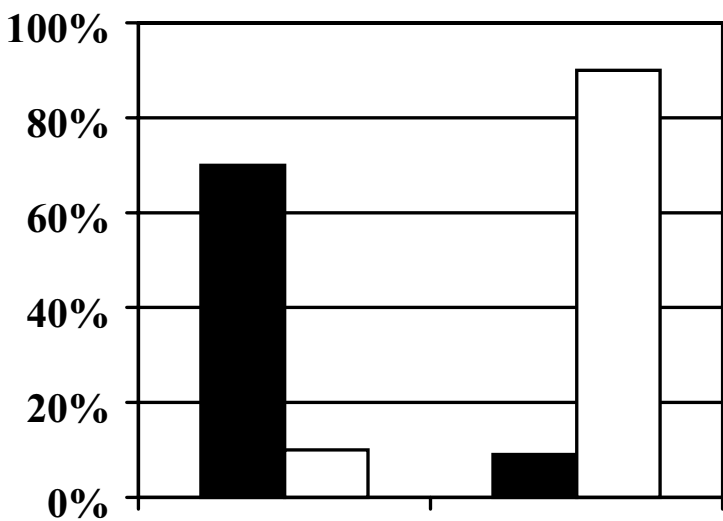

1988

1997
Lotus 1-2-3

$\square$ Microsoft Excel

High End Desktop Publishing

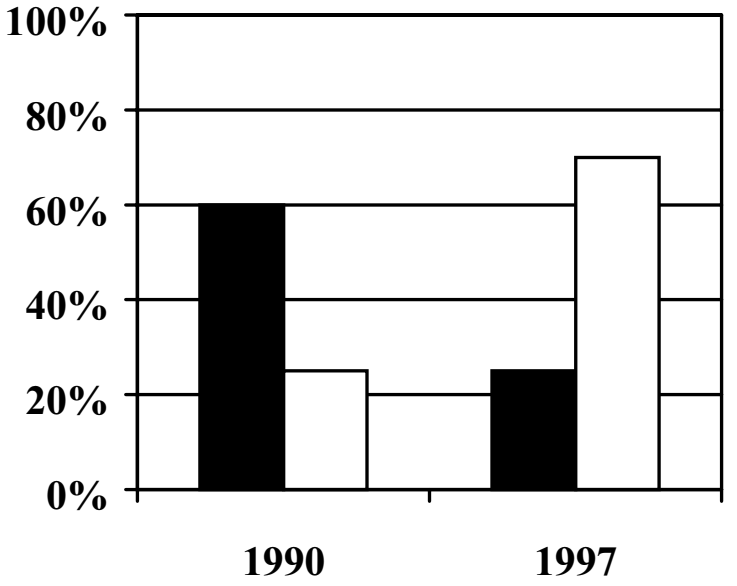

Adobe Pagemaker $\square$ Quark's QuarkXPress

Source: Margolis and Liebowitz (1999); Evans, Nichols, and Reddy (1999). 
Table 1: Top 20 Companies Ranked By Market Value (in Billions of Dollars) as of December 31, 1970, 1985 , and 2000

\begin{tabular}{|c|c|c|c|c|c|c|}
\hline & - 1970 - & & - $1985-$ & & $-2000-$ & \\
\hline Rank & Company & $\begin{array}{c}\text { Market } \\
\text { Value }\end{array}$ & Company & $\begin{array}{c}\text { Market } \\
\text { Value }\end{array}$ & Company & $\begin{array}{c}\text { Market } \\
\text { Value }\end{array}$ \\
\hline 1 & IBM Corp & $\$ 36.4$ & IBM Corp & $\$ 95.7$ & General Electric Co & $\$ 475.0$ \\
\hline 2 & AT\&T Corp & $\$ 26.8$ & Exxon Corp & $\$ 40.3$ & Exxon Mobil Corp & $\$ 302.2$ \\
\hline 3 & General Motors Corp & $\$ 23.0$ & General Electric Co & $\$ 33.2$ & Pfizer Inc & $\$ 290.2$ \\
\hline 4 & Exxon Corp & $\$ 16.4$ & AT\&T Corp & $\$ 26.7$ & Cisco Systems Inc & $\$ 275.0$ \\
\hline 5 & Eastman Kodak Co & $\$ 12.2$ & General Motors Corp & $\$ 22.3$ & Citigroup Inc & $\$ 256.4$ \\
\hline 6 & Sears Roebuck \& Co & $\$ 11.8$ & Royal Dutch Pet & $\$ 16.9$ & Wal-Mart Stores & $\$ 237.3$ \\
\hline 7 & Texaco Inc & $\$ 9.5$ & British Telecom & $\$ 16.8$ & Microsoft Corp & $\$ 230.6$ \\
\hline 8 & General Electric Co & $\$ 8.5$ & Du Pont De Numours & $\$ 16.3$ & American International Group & $\$ 228.2$ \\
\hline 9 & Xerox Corp & $\$ 6.8$ & Toyota Motor Corp & $\$ 16.2$ & Vodafone Group & $\$ 219.7$ \\
\hline 10 & Gulf Corp & $\$ 6.7$ & Amoco Corp & $\$ 16.0$ & Merck \& Co & $\$ 215.1$ \\
\hline 11 & Du Pont De Nemours & $\$ 6.3$ & Bellsouth Corp & $\$ 15.0$ & Nokia Corp & $\$ 202.4$ \\
\hline 12 & Ford Motor Co & $\$ 6.1$ & Sears Roebuck \& Co & $\$ 14.2$ & Intel Corp & $\$ 202.3$ \\
\hline
\end{tabular}


Table 1 (continued):

\begin{tabular}{|c|c|c|c|c|c|c|}
\hline & - 1970 - & & - $1985-$ & & $-2000-$ & \\
\hline Rank & Company & $\begin{array}{c}\text { Market } \\
\text { Value }\end{array}$ & Company & $\begin{array}{c}\text { Market } \\
\text { Value }\end{array}$ & Company & $\begin{array}{c}\text { Market } \\
\text { Value }\end{array}$ \\
\hline 13 & Royal Dutch Pet & $\$ 6.0$ & Chevron Corp & $\$ 13.0$ & GlaxoSmithKline & $\$ 201.9$ \\
\hline 14 & Mobil Corp & $\$ 5.8$ & Mobil Corp & $\$ 12.4$ & Oracle Corp & $\$ 162.2$ \\
\hline 15 & Minnesota Mining \& Mfg Co & $\$ 5.6$ & American Express & $\$ 11.8$ & SBC Communications Inc & $\$ 161.6$ \\
\hline 16 & Avon Products & $\$ 5.1$ & Procter \& Gamble Co & $\$ 11.7$ & BP Amoco & $\$ 155.5$ \\
\hline 17 & Coca-Cola Co & $\$ 5.0$ & Standard Oil Co & $\$ 11.7$ & Coca-Cola Co & $\$ 151.1$ \\
\hline 18 & Procter \& Gamble Co & $\$ 4.7$ & Matsushita Electric & $\$ 11.5$ & IBM Corp & $\$ 150.8$ \\
\hline 19 & Chevron Corp & $\$ 4.6$ & Atlantic Richfield Co & $\$ 11.5$ & Johnson \& Johnson & $\$ 146.1$ \\
\hline 20 & ITT Industries & $\$ 3.6$ & Eastman Kodak Co & $\$ 11.4$ & EMC Corp & $\$ 145.5$ \\
\hline
\end{tabular}

Source: FactSet Research Systems, Inc (2001). FactSet collects financial data from the 10-Q's of the firms with outstanding securities publicly traded on all U.S. markets. 
Table 2: 1997 R \& D Expenditures Relative to Sales

\begin{tabular}{|c|c|c|c|c|}
\hline Company & $\begin{array}{c}\text { R \& D } \\
\text { Expenditures }\end{array}$ & Sales & $\begin{array}{c}\text { R \& D } \\
\text { Intensity }\end{array}$ & $\begin{array}{l}\text { Industry } \\
\text { Category }\end{array}$ \\
\hline Genentech Inc & $\$ 403.3$ & $\$ 948$ & $42.5 \%$ & Pharmaceuticals \\
\hline Chiron Corp & $\$ 296.5$ & $\$ 1,056$ & $28.1 \%$ & Pharmaceuticals \\
\hline Novell Inc & $\$ 282.7$ & $\$ 1,007$ & $28.1 \%$ & Prepackaged Software \\
\hline Amgen Inc & $\$ 630.8$ & $\$ 2,401$ & $26.3 \%$ & Pharmaceuticals \\
\hline Advanced Micro Devices & $\$ 467.9$ & $\$ 2,356$ & $19.9 \%$ & Electronic components \\
\hline National Semiconductor Corp & $\$ 482.0$ & $\$ 2,537$ & $19.0 \%$ & Electronic components \\
\hline Pharmacia \& Upjohn Inc & $\$ 1,217.0$ & $\$ 6,710$ & $18.1 \%$ & Pharmaceuticals \\
\hline LSI Logic Corp & $\$ 229.1$ & $\$ 1,290$ & $17.8 \%$ & Electronic components \\
\hline Microsoft Corp & $\$ 1,925.0$ & $\$ 11,358$ & $16.9 \%$ & Prepackaged software \\
\hline Lilly (ELI) \& Co & $\$ 1,382.0$ & $\$ 8,518$ & $16.2 \%$ & Pharmaceuticals \\
\hline DSC Communications Corp & $\$ 252.1$ & $\$ 1,575$ & $16.0 \%$ & Telephone equipment \\
\hline Analog Devices & $\$ 196.1$ & $\$ 1,243$ & $15.8 \%$ & Electronic components \\
\hline Guidant Corp & $\$ 208.3$ & $\$ 1,328$ & $15.7 \%$ & Medical instruments \\
\hline
\end{tabular}


Table 2 (continued):

\begin{tabular}{|c|c|c|c|c|}
\hline Company & $\begin{array}{c}\text { R \& D } \\
\text { Expenditures }\end{array}$ & Sales & $\begin{array}{c}\text { R \& D } \\
\text { Intensity }\end{array}$ & $\begin{array}{l}\text { Industry } \\
\text { Category }\end{array}$ \\
\hline Pfizer Inc & $\$ 1,928.0$ & $\$ 12,504$ & $15.4 \%$ & Pharmaceuticals \\
\hline Applied Materials Inc & $\$ 567.6$ & $\$ 4,074$ & $13.9 \%$ & Machinery \\
\hline Cabletron Systems & $\$ 181.6$ & $\$ 1,377$ & $13.2 \%$ & Computer networking equipment \\
\hline Silicon Graphics Inc & $\$ 479.1$ & $\$ 3,663$ & $13.1 \%$ & Electronic computers \\
\hline Bay Networks Inc & $\$ 269.8$ & $\$ 2,093$ & $12.9 \%$ & Computer networking equipment \\
\hline Monsanto Co & $\$ 939.0$ & $\$ 7,514$ & $12.5 \%$ & Industrial chemicals \\
\hline Schering-Plough & $\$ 847.0$ & $\$ 6,778$ & $12.5 \%$ & Pharmaceuticals \\
\hline General Instrument Corp & $\$ 207.8$ & $\$ 1,764$ & $11.8 \%$ & Communications equipment \\
\hline Lucent Technologies Inc & $\$ 3,100.6$ & $\$ 26,360$ & $11.8 \%$ & Telephone equipment \\
\hline Medtronic Inc & $\$ 297.2$ & $\$ 2,605$ & $11.4 \%$ & Medical instruments \\
\hline Qualcomm Inc & $\$ 235.9$ & $\$ 2,096$ & $11.3 \%$ & Communications equipment \\
\hline Texas Instruments Inc & $\$ 1,075.0$ & $\$ 9,750$ & $11.0 \%$ & Electronic components \\
\hline American Home Products Corp & $\$ 1,558.0$ & $\$ 14,196$ & $11.0 \%$ & Pharmaceuticals \\
\hline
\end{tabular}


Table 2 (continued):

\begin{tabular}{lcccc}
\hline \multicolumn{1}{c}{ Company } & $\begin{array}{c}\text { R \& D } \\
\text { Expenditures }\end{array}$ & Sales & $\begin{array}{c}\text { R \& D } \\
\text { Intensity }\end{array}$ & $\begin{array}{c}\text { Industry } \\
\text { Category }\end{array}$ \\
\hline Abbott Laboratories & $\$ 1,302.4$ & $\$ 11,883$ & $11.0 \%$ & Pharmaceuticals \\
Cisco Systems Inc & $\$ 698.2$ & $\$ 6,440$ & $10.8 \%$ & Computer networking equipment \\
3COM Corp & $\$ 581.6$ & $\$ 5,420$ & $10.7 \%$ & Computer networking equipment \\
Boston Scientific Corp & $\$ 196.7$ & $\$ 1,872$ & $10.5 \%$ & Medical instruments \\
Oracle Corp & $\$ 719.1$ & $\$ 7,144$ & $10.1 \%$ & Prepackaged software \\
\hline
\end{tabular}

Source: Shepherd and Payson (1999, Table 3). Data are drawn from Standard \& Poor's Compustat, Englewood, CO. 
Table 3: "Market" Shares in High-Technology Industries

\begin{tabular}{llcc}
\hline \multicolumn{1}{c}{$\begin{array}{c}\text { "Product } \\
\text { Market" }\end{array}$} & $\begin{array}{c}\text { "Geographic } \\
\text { Market" }\end{array}$ & $\begin{array}{c}\text { Leading } \\
\text { Firm }\end{array}$ & $\begin{array}{c}\text { "Market } \\
\text { Share" }\end{array}$ \\
\hline Narrowband Internet Access & United States & AOL & $50 \%$ \\
Internet Routers & Worldwide & Cisco & $80 \%$ \\
Online Auctions & Worldwide & eBay & $80 \%$ \\
Injectable antibiotics & United States & GlaxoSmithKline & $77 \%$ \\
Migraine treatment & United States & GlaxoSmithKline & $65 \%$ \\
PC Microprocessors & Worldwide & Intel & $82 \%$ \\
PC Operating Systems & Worldwide & Microsoft & $94 \%$ \\
Personal Digital Assistants & Worldwide & Palm & $66 \%$ \\
Personal Companion Operating Systems & United States & Palm & $83 \%$ \\
Alzheimer's Drug Therapy & United States & Pfizer & $98 \%$ \\
\hline
\end{tabular}

Note: Based upon plausibly defined markets. GlaxoSmithKline’s 77 and 65 percent shares are specifically for the markets of the chemicals, Ceftazidime and Triptan.

Sources: In re America Online, Inc. and Time Warner, Inc., No. C-3989, Complaint, December 14, 2000, ๆ 8; “Building John Chambers' New World Network,” BusinessWeek Online, September 13, 1999, available at <http://www.businessweek.com/1999/99 37/b3646003.htm>; Adam Cohen, “eBay’s Bid to Conquer All," Time.com, February 5, 2001, available at 


\section{Table 3 (continued):}

$<\underline{\text { http://www.time.com/time/magazine/article/0,9171,97068,00.html }>\text {; Complaint, In }}$ re Glaxo Wellcome plc and SmithKline Beecham plc, No. C-3990; "Intel Faces Threats From Rivals as the Microprocessor Giant's Highly Touted Itanium Chip Launch is Delayed," PR Newswire, January 2, 2001; "Client Operating Environments, Market Forecast and Analysis, 2000-2004,” International Data Corporation, Report \# 22346 (June 2000, Table 4); “Market Mayhem: Smart Handheld Devices Market Forecast and Analysis, 1999-2004,” International Data Corporation, Report \# 22430 (June 2000, Table 47); “Pocketful of PCs?” International Data Corporation, Report \# 22184 (May 2000, Table 1); "Gartner's Dataquest Says Oracle is No. 1 Database Software Leader in the World, Three Years Running," Oracle Press Release, May 4, 2000, available at $<\underline{\mathrm{http}}: / / \mathrm{www}$. oracle.com/corporate/press/index.html?198762.html $>$; "FTC Order Clears Way for \$90 Billion Merger of Pfizer, Inc. and Warner Lambert Company”, FTC press release, June 19, 2000; "Worldwide Workstation Census, Forecast and Analysis, 1999-2004," International Data Corporation, Report \# 22183 (May 2000, Table 1) (Based on shipments, Sun's worldwide share is 57\%; excludes branded personal workstations). 